\title{
Over the Caribbean Top: Community Well-Being and Over-Tourism in Small Island Tourism Economies
}

\author{
Ryan R. Peterson ${ }^{1}$ (])
}

Received: 9 March 2020 / Accepted: 23 October 2020

(C) Springer Nature Switzerland AG 2020

\begin{abstract}
The Caribbean is one of the most tourism-intense regions of the world with rising levels of over-tourism, especially in dependent small island tourism economies (SITE). More critically, mounting socio-ecological pressures are compounded by increasing climate change and enduring social vulnerabilities, thereby challenging traditional policies and paradigms of growth and sustainability. Drawing on previous studies of inclusive development and community well-being, this research paper frames and extends the phenomenon of over-tourism from a political economic perspective. Based on a historical account of small island tourism development, an in-depth case study of Aruba is presented. Recognized internationally as the 'One Happy Island' and one of the most tourism-dependent small island economies, the findings yield a contextualized understanding of the complex and dynamic nature of over-tourism, and identify the main antecedents and effects of over-tourism. The study discusses the evolving economic disconnectedness, environmental decay, social inequality, and institutional failures. The findings describe the role of institutional capture and policy drift which stem primarily from political as well as market forces, and have resulted in a gradual marginalization of community well-being and agency. The paper proposes an extended conceptualization of over-tourism in small island tourism economies by explicitly recognizing that the crux of the over-tourism conundrum in SITE is political in nature and institutional by nurture. Recommendations are provided for transitioning towards community-driven development by building capabilities and pathways for innovation, internalization, and institutionalization in order to strengthen the resilience of small island tourism development.
\end{abstract}

Keywords Over-tourism $\cdot$ Climate change $\cdot$ Community well-being $\cdot$ Institutions $\cdot$ Political economy $\cdot$ Resilience $\cdot$ Caribbean

Ryan R. Peterson

rpeterson@cbaruba.org

1 Division Manager Economic Policy \& Financial Stability, Central Bank of Aruba, Oranjestad, Aruba 


\section{Introduction}

What started as a casual affair almost a century ago has today turned into one of the most vibrant and fastest growing industries. Up until the COVID-19 pandemic, the Caribbean was one of the most tourism-intense regions of the world with international tourism contributing, on average, to $20 \%$ of exports, $15 \%$ of GDP (Gross Domestic Product), and 14\% of labor (WTTC 2019). Likewise, accounting for at least $13 \%$ of capital investments, international tourism is one of the most resource-intense industries, including financial, human, and natural resources in the Caribbean (McElroy and Pearce 2006). Over the past 50 years, Caribbean tourism arrivals have grown tenfold, from less than 5 million visitors during the early 1970's to well over 50 million tourists today and is expected to continue to grow in the next decade (WTTC 2019).

Yet paradoxically, despite this significant and continued tourism growth, there are increasing signs that economic growth has largely stagnated across the Caribbean, especially in the smaller and more tourism-dependent island economies (Acevedo et al. 2017; Ruprah et al. 2014; Peterson 2019; Leigh et al. 2017). Initial evidence suggests that the surge in international tourism has not contributed significantly to the lackluster economic growth since the early 2000's (Chamon et al. 2017). This precarious reality is consistent with previous studies reporting stagnant growth and diminishing productivity in Caribbean tourism economies (Ruprah 2014; Peterson 2016), which could be indicative of a maturing of tourism destinations along the tourism life cycle (Butler 1980), or more poignantly, a self-destructive tourism fetish with growth and expansion beyond the destination's socio-ecological capacities (Higgins-Desbiolles 2018). The confluence of enduring tourism growth with diminishing economic development in small island tourism economies (SITES) raises serious questions about the role and contribution of tourism for inclusive development and community well-being in the Caribbean (UNSDG 2018), especially considering the complex of economic, health, and environmental shocks in addition to the longstanding social vulnerabilities and institutional weaknesses (IMF 2017; Ruprah et al. 2014; Peterson 2019).

Whereas tourism specialization is traditionally associated with economic production and growth (Cannonier and Galloway 2019; De Vita \& Kyaw 2016; Marsiglio 2018), the adverse externalities thereof are, however, also well established (Daye et al. 2008; Duval 2004; Gossling 2002; Hall and Williams 2008; McElroy 2003; Peterson 2009; Wilkinson 1989). Furthermore, the relationship between tourism specialization and economic growth is moderated by absorptive capacities (Acemoglu \& Robinson 2012; Baldacchino 2006; Brautigam and Woolcock 2001; Peterson et al. 2017), which describe the optimum level of tourism specialization that can be assimilated and absorbed by an economy before reaching an inflection point after which tourism specialization experiences diminishing returns and negative externalities (De Vita \& Kyaw 2016; Marsiglio 2018).

In terms of the tourism surge in the Caribbean, McElroy and Pearce (2006) contends that part of the problem in the Caribbean is that much of the tourism growth since the early 1990's too fast, unregulated, and fragmented. According to Farrell and Runyan (1991), this rapid and unbalanced growth of tourism produces an inherent propensity for environmental overrun and sociocultural disruption, which in due course affect economic sustainability and societal well-being. As the intensity and concentration of tourism growth increases, the capacity of delicate socio-ecological island systems to absorb these changes can 
be drastically exceeded and may produce undesirable resource degradation (Farrell and Runyan 1991), ironically destroying the very seeds of their previous success.

When reviewing the history of tourism in the Caribbean, it is blatantly apparent that growth rather than development remains the overriding focus. A perusal of Caribbean tourism destination websites and the Caribbean Tourism Organization (CTO 2020) reveals that the dominant modus operandi is geared at increasing arrivals and industry revenues, attracting investments, creating jobs, and expanding cruise-lines and accommodations infrastructures; all in the name of economic growth and wealth hoarding. Exemplary of this continued tourism rhetoric is the recent Caribbean push towards inclusive tourism development by focusing on the market acceptance of new tourism services and how community tourism can support product differentiation with the ultimate benefit being the creation of a distinctive tourism brand that stimulate economic growth, productivity, and competitiveness (CTO 2019). Still couched within a narrow neoliberal tourism agenda, quality of life, shared value, environmental conservation, and community well-being are at best subjugated in national tourism policies that pay little more than lip service to the various principles of inclusiveness, integrity, equity, and sustainability (Daye et al. 2008; Duval 2004; Joppe 2019; Peterson 2009; Scheyvens and Biddulph 2017).

Even if considered as an afterthought or part of the tourism destination's strategy, no formal system for measuring and monitoring non-economic impacts is implemented. Contrary to the espoused national agendas for a sustainable tourism destination, in situ political agendas are largely cloaked for sustaining a tourism industry and have largely eclipsed social rights and responsibilities, de facto subduing the role of government and civic organizations to govern for the general - and future - well-being of society (Higgins-Desbiolles 2018). More importantly, many small island communities across the Caribbean continue to scream in silence for responsible and inclusive tourism (Cole 2007; Duval 2004; Peterson et al. 2020). Reminiscent of Polanyi (1944) and despite some of the nascent benefits of tourism, Caribbean societies seem to have become largely subservient to international tourism markets, rather than tourism markets fostering societal well-being on Caribbean terms (Duval 2004; Pattulo 1996; Sheller 2003). In fact, community and small business tourism in the Caribbean oftentimes operate within a context where their viability is largely determined by global and national actors (Daye et al. 2008).

The enduring fixation on constant increases in tourism volumes and economic value, and the persistent use and promotion of conventional tourism (economic) growth metrics, are testimony to an enduring obsession with physical expansion that has plagued much of the Caribbean; one that is intimately connected to destination politics, power, and political cycles (Acemoglu and Robinson 2012; Bishop 2010; Cole 2007; Daye et al. 2008; Duval 2004; McElroy and De Albuquerque 2002; Peterson et al. 2017). In fact, the political economy of Caribbean island tourism is oftentimes riddled by exclusion and extraction - rather than inclusion and regeneration - as witnessed by several tourism-instigated social disturbances and environmental destruction across the Caribbean since the late 1970's (Bishop 2010). Over the past two decades, several studies have cautioned against the tourism sprawl of social exclusion and ecological decay, and the dire implications thereof in the long run (Daye et al. 2008; Duval 2004; Joppe 2019; McElroy and De Albuquerque 2002; Richter 1994). 
Moreover, economic considerations and benefits of tourism growth and specialization tend to induce 'tourism myopia' - a short-term growth orientation on tourism arrivals, receipts, and (tax) revenues - and trigger a gradual tourism overshoot of socioecological ceilings with significant costs in the medium to long term (Dodds and Butler 2019; Joppe 2019; Marsiglio 2017; Raworth 2017). According the Richter (1994), it is ironic that the pace of tourism can do more damage to the societies in which it flourishes through myopic expansion than by community-inclusive development. Likewise, Crandall (1994) concludes that while tourism is accepted as a significant boon to local economies, there is little realization on the part of tourism elites - those that benefit most from tourism without carrying the costs - that tourism leads to economic spillovers, social changes, and ecological challenges, especially when unplanned or uncontrolled. Although certainly not a new experience, this mounting tourism spillover effect has recently been coined over-tourism (Dodds and Butler 2019; WTTC 2019).

Although over-tourism is usually defined in terms of the adverse impact of excessive tourism on (parts of) a destination that influences perceived quality of life of citizens and/or quality of visitor experiences in an undesired way (UNWTO 2018), this narrow conceptualization disregards or downplays the political economic role of tourism, especially in the Caribbean that is generally characterized by dense and tightly-knit social networks (Benedict 1967; Daye et al. 2008). From a political economic perspective, Daye et al. (2008) contend that the key to investigating and understanding Caribbean tourism development, and especially the 'tourism over-run', is the historical context, local realities, and the 'invisible' interactions that influence tourism policies and decisions. Likewise, Duval (2004) argues that understanding Caribbean tourism requires a historical and contextual understanding of the less-observable social mechanisms and formative political, economic, social, and institutional processes that shape tourism policies and institutional behaviors in small islands. Beyond the physical notions or symptoms of overcrowding or carrying capacity (UNWTO 2018; WTTC 2019), this study contends that, at its core, over-tourism is a manifestation of certain institutional powers and processes, and represents the social overpowerment or disempowerment of a destination community's agency (Daye et al. 2008; Duval 2004; Hall and Williams 2008; Joppe 2019; McCool and Lime 2001; Moscardo 2015; Richter 1994; Williams and Ponsford 2008).

Within contemporary studies and conventional policies on (over-) tourism, the focus is mainly on rational policy formulation and narrowly defined socio-economic processes, rather than on the political context and institutional frame in which power is wielded and governed to preserve and control existing political economic structures and tourism institutions (Acemoglu \& Robinson 2012; Dodds and Butler 2019; Hall and Williams 2008; Joppe 2019). In reflecting on previous studies in the Caribbean, Duval (2004) argues that too often research interprets results through the lens of apolitical and ahistorical perspectives. Thus, the fundamental role of institutional framing and failures remains relatively under-scrutinized in studies on over-tourism (Duval 2004; Hall and Williams 2008; Joppe 2019).

Furthermore, whereas previous studies on over-tourism relate mostly to metropolitan and city districts, over-tourism in small island communities remains largely void of empirical investigation. Moreover, research on international tourism in the Caribbean focuses almost exclusively on the independent (sovereign) small island tourism states, while dependent (non-sovereign) island tourism economies are generally less 
scrutinized and often excluded, largely due to their non-sovereign political status. Ironically, these subnational island jurisdictions (SNIJs) are oftentimes relatively more tourism-intense and prone to over-tourism (Baldacchino 2006; McElroy and Pearce 2006; Peterson 2019; WTTC 2019).

Considering the aforementioned challenges in contemporary Caribbean tourism and the lack of extensive empirical studies on over-tourism in SITES, this paper studies the political economy of over-tourism in a non-sovereign SITE and presents a historical case study on the evolution and socio-ecological impacts of tourism growth in Aruba. The aim of the in-depth case study is to explore the main antecedents, processes, and effects of over-tourism, and contribute to a more comprehensive and contextualized understanding of the complexity and dynamics of over-tourism within the context of a contemporary small island community in the Caribbean. Hence, this study seeks to address and explain how and why contemporary over-tourism emerges and endures in a Caribbean SITE and therein question existing paradigms and maxims of tourism institutionalization. In stretching the conventional conceptualization of over-tourism and exploring the institutional roots of excessive and unregulated tourism growth in the Caribbean, this study aims to explain the political-economic development of overtourism from within a Caribbean island perspective.

Internationally acclaimed as the 'One Happy Island' and one of the most tourismdependent small island economies (McElroy and Pearce 2006; WTTC 2019), the case of Aruba is examined to understand how over-tourism and the impacts thereof have evolved over the past 30 years. Aruba is a sub-national island jurisdiction within the Kingdom of the Netherlands and part of the Dutch Caribbean. Aruba is geographically located in the Southern Caribbean Sea on the peripheral of the Caribbean hurricane belt. With a registered population of an estimated 112,000, Aruba has a total surface area of $180 \mathrm{~km}^{2}$, and a coastline of $69 \mathrm{~km}$. Considering Aruba's politically dependent status and the extensive tourism history dating back to the early 1960's, the case study draws on a mixed method of qualitative and quantitative methods to examine the political economic and socio-ecological dynamics of over-tourism from a holistic small island perspective. Based on an extensive historical economic survey of various social, economic, and environmental policies and indicators, the focal drivers and community impacts of over-tourism are identified.

The remainder of this paper is structured as follows. In "Theoretical Background" section, the theoretical background of this study is discussed by reviewing the conceptual origins of and previous studies on over-tourism, inclusive tourism, communitybased tourism, and community well-being. The research design and methodology are described in "Research Design" section, followed by a presentation of the main findings in "Results" section. The conclusions and recommendations are presented in "Conclusion" section.

\section{Theoretical Background}

Conventionally, over-tourism describes the adverse impacts of uncontrolled tourism growth - an overshoot of tourism - that influences the (perceived) well-being of citizens and the degradation of natural habitats and ecologies, which result in diminishing visitor experiences and expenditures, and consequently, stagnating 
economic returns (UNWTO 2018). Over-tourism portrays relentless, frequently unregulated, tourism growth that has moved beyond the level of acceptable change and absorptive capacity in a destination due to significant levels of tourism intensity (total visitors-to-population), tourism density (visitors per $\mathrm{km}^{2}$ ), and tourism dependency (tourism exports-to-GDP). The compounding effects result in significant pressures on infrastructure (i.e., congestion, transportation, and energy), resource consumption and pollution (i.e., leakage and waste), spatial and cultural alienation (i.e., real-estate and social identity), and visitors' experiences and residents' quality of life (CREST 2018; WTTC 2019).

However, contrary to the mainstream beliefs and accepted definitions that overtourism is concerned with the volume of visitors and challenges of, e.g., crowding and congestion, the overshoot by tourism is also reflected in the values and behavioral norms of a destination's institutions, community, and visitors (CREST 2018; Cole 2007; Joppe 2019). Par example, disrupting fragile coastal zones with motorized vehicles, disturbing sensitive turtle-nesting areas, or trashing bio-diverse marine parks are mere examples where the number of visitors may not overwhelm per se. Likewise, a single immoral act by a visitor can outrage a community, especially when acts are prohibited or unlawful, yet are tolerated by authorities out of concern for a possible tourism backlash. In the long run, tourism behaviors may become institutionalized until changes are no longer accepted or acceptable by the local community (Dodds and Butler 2019; Joppe 2019; Williams and Ponsford 2008).

More importantly, the institutional behaviors and ethics of destination governments and authorities are fundamental to understanding the complexity and dynamics of overtourism, especially within the context of small island societies with strong political ties (Benedict 1967; Bishop 2012). The crux of the over-tourism conundrum and its resolution are well beyond the boundaries of tourism as an industry; they are political by nature and institutional by nurture (Baldacchino 2005; Joppe 2019; Peterson et al. 2017). Thus, in terms of concept stretching (Pearce and Butler 1999) and beyond conventional definitions of over-tourism that emphasize tourism intensity and visitor density, destination values and community norms as well as political-institutional ideologies and behaviors are a defining, albeit oftentimes tacit, element of contemporary over-tourism (Duval 2004; Joppe 2019).

By deconstructing over-tourism from an emic island perspective through a politicaleconomic institutional lens (Bishop 2012; Duval 2004), this study addresses the limitations of traditional normative and reductionistic tourism-centric approaches (Daye et al. 2008), carrying capacity fallacies (McCool and Lime 2001), sustainable tourism oxymorons (Duval 2004; Joppe 2019; Peterson et al. 2017), and conceptualizes over-tourism from a contextualized perspective in which both norms and networks of purpose, power, people, and place take center stage in social construction of tourism development and institutional behaviors (Cloutier et al. 2019; Hall and Williams 2008; Joppe 2019; Richter 1994).

Although the adverse effects of excessive tourism are recognized as symptomatic of over-tourism (UNWTO 2018), fundamentally, over-tourism reflects the exclusion of a destination's community and agency to co-determine its tourism development (Daye et al. 2008; Giampiccoli and Saayman 2018); it is essentially about the social overpowerment or disempowerment of a community's voice and choice with regard to the desire, direction, and development of tourism within a specific destination (Hall 
and Williams 2008; Joppe 2019; McCool and Lime 2001; Moscardo 2008; Richter 1994; Scheyvens and Biddulph 2017; Williams and Ponsford 2008). This underscores both the absence and, consequently, the importance of inclusive tourism governance and community-driven tourism development for safeguarding community well-being (Moscardo 2008; Scheyvens and Biddulph 2017).

The genesis of over-tourism dates back to at least the 1970's and 1980's when initial concerns were raised about the potential adverse social and environmental impacts of uncontrolled tourism growth, and consequently, the long-run economic repercussions thereof (Bosselman 1978; Budowski 1976; Butler 1980; Cohen 1978; Doxey 1975; Dunkel 1984; Farrell and Runyan 1991; Getz 1983; Holder 1988; Innskeep 1994; Mathieson \& Wall 1982; Pearce 1985; Richter 1994; Wilkinson 1989). By the early 2000's, several empirical studies reported on the negative externalities of tourism in SITES (Bishop 2010; Duval 2004; McElroy 2003 2006; Sheller 2003). Over the past decade, further evidence has been forthcoming on the role and rise of over-tourism, albeit mainly focused on metropolitan areas and cities (Capocchi et al. 2019; CREST 2018; Dodds and Butler 2019; WTTC 2019) and World Heritage sites (Milano et al. 2019; Musikanski et al. 2019). However, echoing some of the critique on over-tourism (Joppe 2019), much of the conceptual and intellectual work on Caribbean island tourism has not progressed much beyond an embryonic stage of objectivistic reductionism (Daye et al. 2008; Duval 2004; Pearce and Butler 1999; Peterson et al. 2017).

Over-tourism extends previous theoretical frameworks and models of tourism lifecycles and complex adaptive tourism systems. The origins can be traced back to notions of the tourism destination lifecycle (Butler 1980) and tourism carrying capacity (Mathieson and Wall 1982), which have been widely discussed in the Caribbean. Furthermore, the concept of over-tourism underscores the nonlinear, interdependent, and dynamic nature of tourism systems (Farrell and Twinning-Ward 2004), which encompass several interacting social, political, economic, ecological, and digital subsystems, especially within the small(er) scale of island communities (Peterson et al. 2017). These complex adaptive tourism systems are 'nested' or embedded within social and political ecologies and often evolve in distinct ways with extensive cascades of uncertain, path dependent, and long-term effects (Dodds and Butler 2019; Farrell and Twinning-Ward 2004).

As a concept, over-tourism is rooted in development economics and discussions on overdevelopment, overdependency, and overconsumption (Kohr 1977; Meier and Stiglitz 2001). From a post-development theoretical perspective (Cowen and Shenton 1996), over-tourism refers to the social inequality and the environmental destruction due to excessive tourism consumption and tourism-related infrastructure expansion. Over-tourism is conceptually embedded in the study of how economies grow and societies change over the course of history (Meier and Stiglitz 2001), and is frequently viewed in negative terms as the mutually constitutive reverse of inclusive development and inclusive tourism (Gupta and Vegeling 2016; UNSDG 2018; World Bank 2018).

Inclusive development focuses on productive employment as a means of increasing income as well as raising standards of living and community well-being (Gupta and Vegeling 2016; Cloutier et al. 2019). The quality of opportunity and participation in growth, with a special focus on the working poor and the un(der)employed, are integral to inclusive development (Ianchovichina and Lundstrom 2009; Ranieri and Ramos 2013; Rauniyar and Kanbur 2010). In development economics, it is not only the rate of 
real GDP per capita growth that matters, but more importantly, the pattern of labor force participation and income distribution in growth (Meier 2001). Essentially, fostering societal and community well-being for cultivating resilient societies takes center stage in inclusive development.

Gupta and Vegeling (2016) emphasize both the social and ecological aspects of inclusive development. Whereas social elements address community well-being and participation in labor and consumption markets, ecological elements concentrate on the conservation of local ecosystems, the management of ecosystem services, and the regulation of environmental resources. Inclusive development resonates strongly with the community well-being principles of purpose, place, and relation as discussed by Cloutier et al. (2019). These principles describe the nurturing of a shared sense of identity, inclusion, and (intergenerational) equity in societies. Community well-being constitutes a combination of multiple factors and conditions that shape community's quality of life, including, social, environmental, economic, political, and cultural factors, which collectively and holistically, describe a community's happiness and well-being (Cloutier et al. 2019; Musikanski et al. 2019). According to Scheyvens and Biddulph (2017), the ultimate goal of community-based tourism development is to empower the destination's (host) community in four dimensions, i.e., economic, psychological, social, and political.

VanderWeele (2019) underscores multiple objective and subjective dimensions of community well-being, and discusses the importance empowerment, trust, and governance for fostering community well-being. Moscardo (2015) argues that community trust in tourism institutions is essential to strengthen community capacity and enable community-based tourism development. Thereto, community awareness and education, active community involvement as well as community advocacy and the integration of a community's values and aspirations for tourism development are considered pivotal to safeguarding a destination's community well-being (Giampiccoli and Saayman 2018; Moscardo 2019; Scheyvens and Biddulph 2017). In the absence of community trust and institutional credibility, a country may soon find itself drifting along the waves and whims of elitist powers to the detriment of society and environment (Acemoglu and Robinson 2012).

The need for inclusive development stems from the realization that relentless economic growth often gives rise to negative externalities, extractive resource depletions, and exploitative labor practices (Raworth 2017), which are clear and present features of over-tourism and readily acknowledged in Caribbean SITES (Daye et al. 2008; Duval 2004; Island Resource Foundation 1996; McElroy and Pearce 2006; Pattulo 1996; Sheller 2003). In terms of Raworth (2017), over-tourism is sparked when the ecological ceilings and the social foundations of an economy are depleted. According to Scheyvens and Biddulph (2017), one of the most enduring critiques of tourism is its non-inclusive development. They contend that tourism oftentimes provides opportunities for the privileged, creating profits for international (non-local) resorts, and building exclusive enclaves for the rich, thereby excluding the indigenous community, marginalizing local cultures and lifestyles, and depleting scarce natural resources (Scheyvens and Biddulph 2017). Thus, in terms of safeguarding community wellbeing, inclusive tourism governance is not only concerned with the active involvement and purposeful engagement of the community and civic society but also in the participation and distribution of tourism's benefits, i.e., the realization of shared value 
from tourism development (Giampiccoli and Saayman 2018; Moscardo 2008; Peterson et al. 2020; Scheyvens and Biddulph 2017).

Historically, however, previous studies indicate that Caribbean tourism developed in a context of a relatively weak state and marginalized community (Pattulo 1996; Sheller 2003; Daye et al. 2008; Duval 2004; Peterson et al. 2020). Scant policy attention and political commitment has been paid to improving the involvement of the community in tourism development and the subsequent sharing of value. Despite the many calls by international organizations for including the local community in tourism, many contemporary efforts are largely symbolic. Even if and when, local stakeholders and civic organizations are invited to participate in tourism decision-making and policy development, their voices and choices are soon forgotten or neglected when plans are implemented. Merely creating jobs for the community is not sufficient, especially when these jobs are being created for migrant workers. It is therefore essential that communities are empowered and engaged in tourism planning and at the fore of tourism development (Duval 2004; Giampiccoli and Saayman 2018; Moscardo 2008; Peterson et al. 2020; Scheyvens and Biddulph 2017).

The general effects of over-tourism are frequently transmitted through direct as well as indirect channels. Direct channels of over-tourism transmission describe diminishing or negative tourism contribution to GDP, declining average visitor expenditures, increasing import leakages, growing resource consumption, high tourism export concentration, tourism price inflation, and expansive government expenditures. Overtourism also transmits through indirect channels, which effect local communities and natural habitats. Indirect channels of over-tourism transmission include stagnant labor participation rates, limited or declining income equality, uneven income distribution, increasing social costs, foreign-ownership concentration of tourism industry, spatial concentration of tourism industry, real-estate price inflation, environmental degradation, loss of natural habitats, and diminishing contribution of tourism ecological services (Capocchi et al. 2019; Daye et al. 2008; Duval 2004; Hampton and Jeyacheya 2013; Koens et al. 2018; WTTC 2019). However, unlike direct transmission channels of over-tourism, indirect effects often transpire and materialize over extended periods of time and may span several business and political cycles.

In reviewing the progressive development and potential challenges of tourism growth across SITES, McElroy and Pearce (2006) discusses different interrelated causes of a tourism overrun, defined as high-density tourism with damaging levels of visitation due to tourism's sociocultural pressures and environmental footprint. The critical factors that spur over-tourism in the Caribbean include (a) the substantial inflow of foreign private tourism investments; (b) the significant stock and rapid expansion of large-scale accommodation facilities; (c) the growth in air traffic and cruise calls; (d) the increase in labor immigration; and (e) the subsequent rise in unplanned coastal urbanization and real-estate infrastructures (McElroy and Pearce 2006). Previous studies indeed confirm that this system of an interlocked tourism supply chain, including the growth in tourism investments and airlift, and the subsequent expansion of accommodations and required labor, contributes to surging levels of tourism intensity and density in the Caribbean, which gradually engenders a state of over-tourism in SITES.

Likewise, Cole (2007) indicates that an overshoot in Caribbean tourism arises from several interdependent factors, including e.g., (a) surpassing physical limits of beachfront or coastal areas for resort construction, (b) increasing labor migration due to 
limited local workforce, (c) growing visitors' sense of overcrowding, and (d) an escalation in residents feeling overwhelmed or displaced by visitors and/or immigrant workers. The latter describes intensifying sentiments of visitor annoyance and apathy by local communities (Doxey 1975). The unfolding of these events triggers a spiral of demise where surging small island coastal tourism causes increasing crowding, congestion, and contamination (McElroy and De Albuquerque 2002). Frequently, this leads to irreversible ecological destruction, social decay, and aesthetic repulsion, and a further uncontrolled spiraling effect (Dehoorne et al. 2010).

The case in point is especially relevant for SITES that rely on their natural and social ecologies for safeguarding economic development and well-being. Whereas sustainable tourism requires the conservation of ecological integrity and environmental resources, its production is, paradoxically, largely dependent upon the consumption of naturebased tourism experiences (Williams \& Ponsford 2008). Likewise, while much of Caribbean tourism is staged by its cultural authenticity and natural hospitality, which are essentially rooted in a community sense and values of well-being, its production is labor-intensive with exhaustive demands on emotional labor (Shani et al. 2014; Sönmeza et al. 2017). This paradoxical ambiguity has epitomized much of the progress, pitfalls, and perils of Caribbean tourism over the past century (Duval 2004), and underscores the significance of reframing and extending contemporary over-tourism from an emic political-economic perspective.

The confluence of policy and market failures intensify the negative externalities due to several institutional conditions, including: (a) a regulatory deficiency in environmental conservation and enforcement, (b) limited economic diversification and innovation, (c) lopsided (private) benefits and (public) costs of tourism growth, (d) marginal social inclusion and non-civic participation in tourism policy and development, and (e) a strong and persistent bias towards short-term tourism promotion, expansion, and growth (Bishop 2010; Daye et al. 2008; Dodds and Butler 2019; Joppe 2019; McElroy and Pearce 2006; Williams \& Ponsford 2008).

Furthermore, the systemic exclusion and disempowerment of the community in tourism decision-making and development is central to the problematique of overtourism and one of the primary institutional root causes for the uncontrolled and excessive growth and expansion in tourism. Previous studies indicate that inclusive tourism and community involvement are predominantly inhibited by institutional legacies of centralized governance, market-based tourism institutions, coercive or symbolic community consultations, information asymmetries, and structural deficits in labor and environmental regulation, tourism governance, and community education (Cole 2007; Joppe 2019; Giampiccoli and Saayman 2018; Moscardo 2008; Peterson et al. 2020; Scheyvens and Biddulph 2017).

Beyond the normative value systems of neoliberal tourism policies, Williams \& Ponsford (2008) argue that public institutions and agents tend to circumvent regulations and regulatory enforcement largely due to the economic lock-in of the tourism industry. Hall and Williams (2008) describe this tourism lock-in as path dependency, which is conducive to institutional failures (e.g., close personal and political ties, and resource dependency), network failures (e.g., information asymmetry, dissonance, and ignorance of new developments), and capability failures (e.g., lack of shared awareness and institutional learning capabilities). In addition to rent-seeking institutional behaviors, tourism institutions are an outcome of political negotiations and choices, which are 
shaped by the political agency and exercise of preferences and power (Hall and Williams 2008), thereby increasing the risks of institutional capture, which is - beyond tourism density and intensity - integral to deconstructing over-tourism in contemporary island perspective.

Institutional capture occurs when an institution or a (minority) collective of agents acts to secure the commercial or political interests of a specific industry or constituency over and above the general interest of, e.g., the public or the community (Acemoglu \& Robinson 2012). This wide-spread phenomenon in the Caribbean (Bishop 2010; Duval 2004; Daye et al. 2008; McElroy and De Albuquerque 2002; Pattulo 1996; Sheller 2003) frequently leads to a net loss for society and prompts heightened income inequality and social exclusion over the long run (Peterson et al. 2020; Stiglitz 2013). Moscardo (2015) indicates that the social exclusion and the erosion of social capital stem largely from the lack of community involvement, capacity, and advocacy in tourism development, and is one of the main reasons for the growing critique of contemporary tourism, including its adverse impacts. Moreover, free-market tourism policies that seek to grow the industry and increase economic returns in the short run, rarely consider the economic leakages or the adverse downstream implications for society in the long term (Dodds and Butler 2019).

In stretching the concept of over-tourism and underscoring the importance of institutional failures, Dodds and Butler (2019) conclude that a key political economic enabler of over-tourism is the mutually reinforcing attitude, or mindset, of both private and public sector stakeholders that favor short-term growth above all else, which subsequently nurtures institutional bonding and 'blindness' (Hall and Williams 2008). Although over-tourism is complex, the fundamental lack of tourism governance and policy prudence by public and private stakeholders, in addition to excluding civic society and local communities from tourism decisions and development, have fostered the unrestricted expansion and negative externalities of tourism growth.

Understanding the role of tourism institutions and institutional regimes in maintaining a certain political economic equilibrium (Acemoglu \& Robinson 2012) is essential in not only understanding the evolution of over-tourism, but more importantly, fundamental to safeguarding of community well-being for strengthening the resilience of SITES. Consequently, this study addresses the institutional problematique of Caribbean over-tourism from a historical and contemporary small island perspective. More specifically, the investigation answers the following questions within the delimited context of a Caribbean SITE: What are the main political economic forces and institutional regimes that influence the propensity for over-tourism? How can the socio-ecological risks of over-tourism be mitigated, and community well-being be fostered for strengthening the resilience of small island tourism development?

\section{Research Design}

The aim of the in-depth case study is to explore the main antecedents, processes, and effects of over-tourism, and contribute to a more comprehensive and contextualized understanding of the complexity and dynamics of over-tourism within the context of a contemporary small island community in the Caribbean. Considering Aruba's politically dependent status and the extensive tourism history in addition to its significant 
tourism density, intensity, and dependency, the case of Aruba is examined to understand how tourism and the impacts thereof have evolved from a historical political economic perspective.

Aruba is a mature small island tourism economy with over 70 years of experience with tourism. From a tourism destination perspective, it is the 'One Happy Island' in the Caribbean (Aruba Tourism Authority 2018). Today, Aruba is ranked amongst the top Caribbean tourism destinations (WTTC 2019) and is considered one of the most trade and tourism-dependent small island economies in the Caribbean, which makes it highly vulnerable to external shocks (Peterson 2019). Descriptive analysis of stylized indicators shows that Aruba is the most tourism-dependent economy in the Caribbean (87\% of GDP) and ranks second and third (after St. Maarten and Bermuda) on, respectively, resort density $\left(+800\right.$ hotel rooms per $\left.\mathrm{km}^{2}\right)$ and tourism density $(+10,500$ visitors per km²) (UNWTO 2018; World Bank 2018; IMF 2019).

The case study draws on a mixed method of qualitative and quantitative methods to examine the political economic and socio-ecological dynamics of over-tourism from a holistic small island perspective. Based on an extensive historical economic survey of various social, economic, and environmental policies and indicators, the focal drivers and impacts of over-tourism are identified. Case study research involves a detailed empirical inquiry that investigates a contemporary phenomenon within its real-life context. The main purpose of a case study is to provide a contextual analysis of the historical conditions and contemporary processes involved in the phenomenon under study. The embedded case study - consisting of both quantitative and qualitative data is an appropriate research methodology in order to explore new multi-faceted concepts with limited empirical evidence (Yin 2009). Although conceptually rooted in previous studies, the political economic and socio-ecological dynamics of over-tourism remains under-theorized and under-scrutinized in empirical research, especially in nonsovereign Caribbean SITES.

The case study combines qualitative and quantitative data analysis in a phased approached, in which the collection and analysis of quantitative economic data is followed by the collection and analysis of qualitative data in order to provide contextual richness (Creswell and Creswell 2018). The validity of research findings is thus strengthened by means of triangulation of theoretical conceptualizations, qualitative data, and quantitative data. However, case study findings are regularly more geared at theory building rather than theory testing (Eisenhardt 1989). Therefore, the results of this study should not be generalized beyond contemporary Caribbean SITES and should be interpreted from a theory development perspective.

In the first qualitative phase of the study, the research focused on collecting and analyzing relevant tourism and non-tourism policy documents that were published between 1970 and 2018. Both historical and national archives were consulted to retrieve a list of national policy documents and tourism plans pertaining to different areas of national development, including, the economy, society, labor markets, education, the environment, and tourism (See References for a complete list of documents sourced and analyzed).

Subsequently, in the spirit of grounded theoretical logic (Glaser 1992) and using semi-structured qualitative coding and memoing, the policy documents were analyzed for types of tourism policies, aims, institutional responsibilities, recommendations, and execution. For each document, key elements were coded with reference to, e.g., specific 
national context, tourism environment, policy decisions, challenges, and development options. Cluster- and pattern-matching techniques were applied to identify and inductively design a hierarchy of themes and sub-themes from the qualitative data and compare these with the (theoretical) antecedents and effects of over-tourism (Yin 2009). Thus, by applying qualitative data analysis, a contextualized tourism framework was inductively constructed based on major themes and historical events across time and space (See Table 1).

The quantitative survey consisted of a historical economic survey. Data was collected by examining available and accessible statistical databases from national tourism and non-tourism authorities involving the Central Bureau of Statistics, the Department of Labor, the Department of Nature and Environment, the Aruba Tourism Authority, the Department of Economic Affairs, and the Central Bank of Aruba. National databases and archives were surveyed to collect data on economic, tourism, labor, social, environmental, and other historical indicators tourism (See References for a complete list of documents sourced and analyzed).

To identify the main antecedents and effects of over-tourism, the data was standardized across several indicators in order to normalize the data and facilitate comparative and inferential analyses. The data was standardized by using a min-max scaling method: $y=(x-\min x) /(\operatorname{maxx}-\min x)$, where $\mathrm{x}$ is the original value and $\mathrm{y}$ is the normalized value between $[0,1]$. Subsequently, to explore the latent (theoretical) structure of the over-tourism construct, in addition to reducing the number of individual variables and the potential multicollinearity, a principal component panel regression (PCPR) analysis - a special form of partial least square regression - was applied, in which the over-tourism construct was regressed on the newly identified components.

In examining the main antecedents of over-tourism, a production-like function was applied consisting of the identified regressors, i.e., the over-tourism antecedent factors. The production function form was estimated as a $\log$-linear relationship using: $\ln (\mathrm{Y})=$ $\mathrm{a} 0+\sum$ ailn $(\mathrm{OTi})+\varepsilon$, with $\mathrm{Y}=$ over-tourism, OT $=$ antecedent factors, and $\mathrm{a}=$ coefficients. To analyze the dynamic (non-linear) effect of over-tourism, quadratic regression analysis was conducted to assess the effect of over-tourism on several socioeconomic and socio-ecological indicators. Based on the parameter estimates of the quadratic regression function, the over-tourism vertex - the threshold or tipping point - was calculated and subsequently compared to the state of over-tourism.

\section{Results}

\section{The Genesis of One Happy Island}

The birth of the Aruban tourism industry dates to 1930's when the first commercial airline landed on Aruba and a guest house was opened in Oranjestad, the capital of Aruba. The official opening of the Aruba Caribbean Hotel as the first luxury resort of Aruba ushered in a new epoch in the development of tourism in the early 1960's. With the early dawning of the tourism industry, the government of Aruba was keen on developing and institutionalizing a new economic pillar (besides the oil refining industry), and a national vision emerged to become 'the little Miami of the Caribbean', reminiscent of the vibrant economic scene in Cuba during the 1950's. 


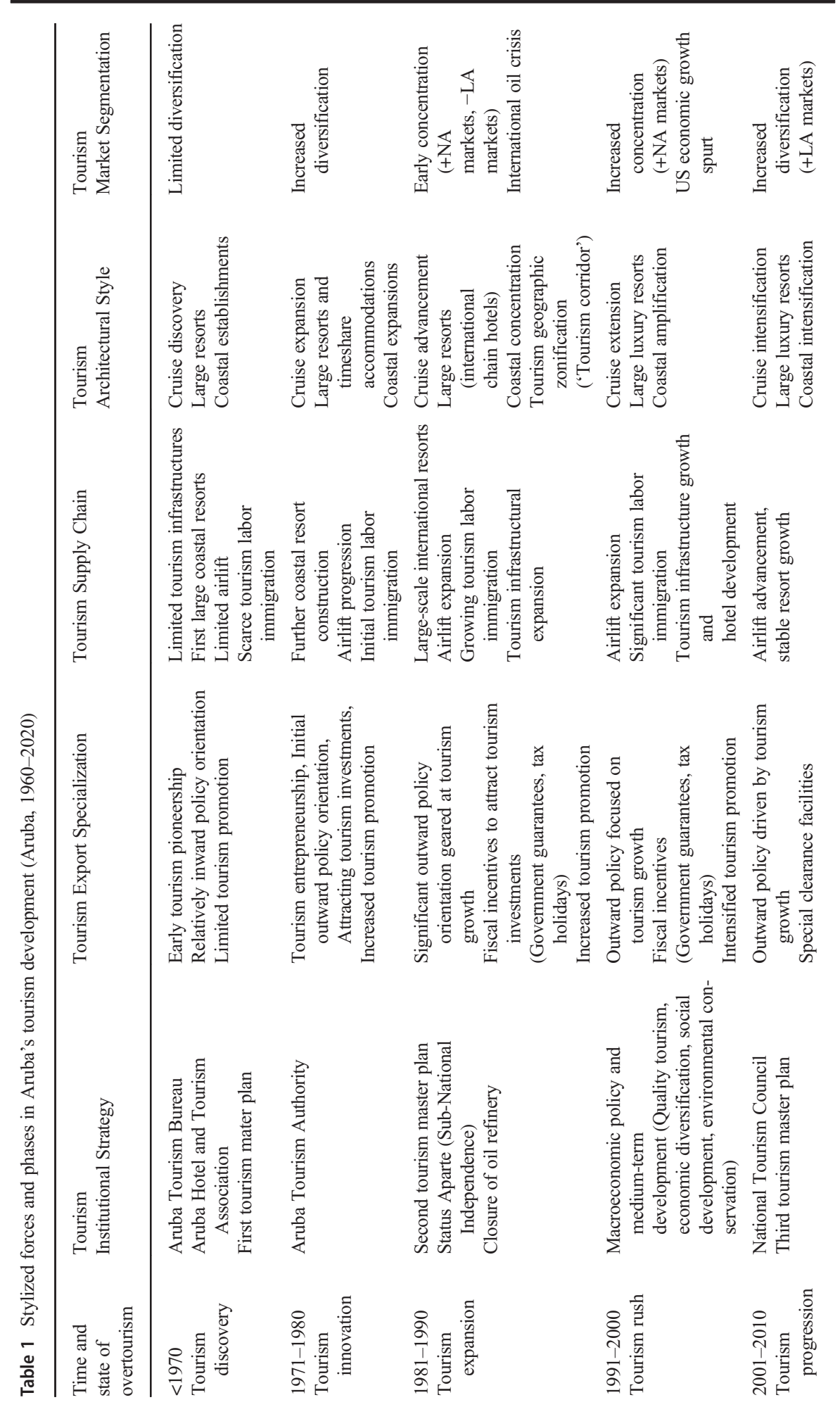




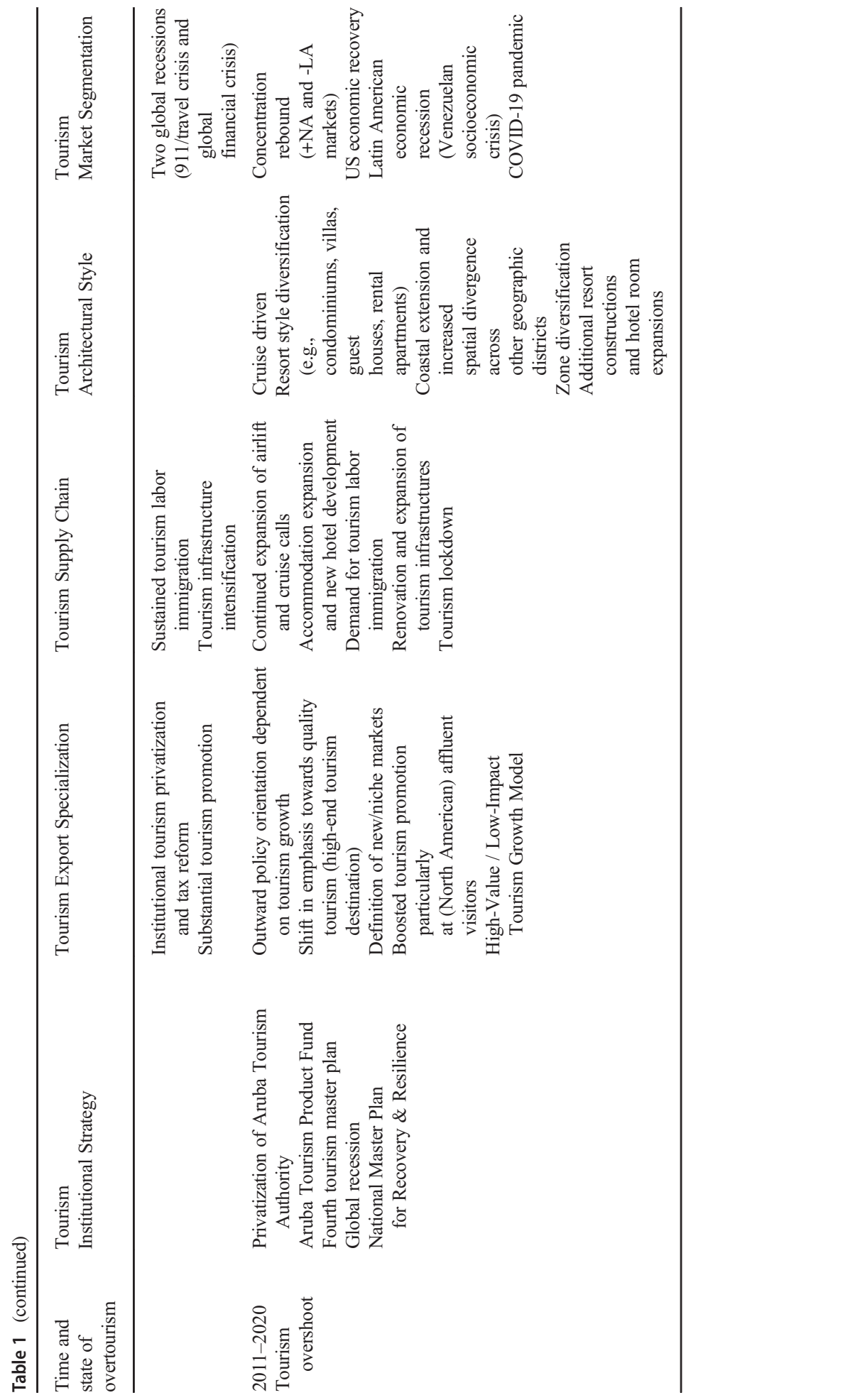


In 1947, the Aruba Tourism Commission (ATC) was established and, subsequently, transformed into the Aruba Tourism Bureau (ATB) in close collaboration with the local tourism industry and international partners. At the time, Aruba accommodated an estimated 900 visitors and three (3) hotels of approximately 100 rooms. In February 1955, the first cruise ship with 300 visitors entered Aruba's harbor. In 1965, the Aruba Hotel Association (AHA) was founded and later changed to Aruba Hotel and Tourism Association (AHATA), thereby incorporating several tourism and hospitality sectors, and solidifying the foundation of the 'One Happy Island'.

Since the early days of tourism innovation, the Government of Aruba pursued a free-market, export oriented economic policy (UNDP 1996). Ever since, the island's tourism policy has been geared at attracting large and mid-scale resorts, and incentivizing international investments (e.g., tax holidays, government guarantees, special concessions, dedicated facilities) for constructing luxury, timeshare, and condominium resorts, expanding air and cruise port infrastructures, and fueling several tourism-related facilities and amenities, such as casino's and golf parks (Cole 2007). This tourism growth policy orientation still holds today with a keen focus on fostering a high-end (quality) tourism destination by attracting affluent tourism, promoting airlift and cruise calls, increasing tourism receipts, upgrading product quality, and safeguarding the Aruban visitor experience (ATA 2018).

During the 1970's, Aruba witnessed a strong expansion of international tourism, which received an extra push with the closing of the oil refinery during the late 1980s. To reinvigorate the economy, the government agency ATB was tasked with opening new markets, increasing airlift, strengthening promotion, and was renamed the Aruban Tourism Authority (ATA). During this period of bolstering tourism growth, a new tourism master plan was developed with the aim of building a 'tourism corridor' (in the North-West region and capital of Aruba) and improve the quality of tourism in order to increase tourism income and revenues. Given the rich environmental and social endowments of the island, tourism was an almost instinctive and natural course of action, which accelerated with continued investments, growth, and expansions during the 1990's and well into the 2010's.

By the early 1990's, Aruba was well on its way on becoming 'little Miami' and there were clear signs of an overheating economy with significant economic growth and inflationary pressures. In the 1997 Article IV mission, the IMF reported:

"Earlier growth rates, based primarily on rapid expansions of the tourism sector, had given rise to a significant population increase, surging housing demand, and incipient inflationary pressures, and a government decision to limit new construction, given nearly full employment and the island's limited physical resources".

Economic growth in Aruba will depend on increased capacity utilization, moves to further upgrade the quality of tourism, and the diversification of the economy." (IMF 1997, p. 2)

Consequently, there were increasing calls to halt hotel constructions and further expansions, and diversify the economy with quality tourism and other high-tech services. In its 1996 country cooperation program, the UNDP concluded: 
"...its medium term development objective is to sustain economic growth by restoring the domestic balance of savings and investment and the external balance of trade, to maintain price stability, and to diversify the economy by creating an environment that fosters private sector investment in sectors other than tourism.

In collaboration with the World Tourism Organization, UNDP will conduct studies on how to improve the quality of tourism in Aruba. This will include a study on the demands of high-income tourists and of Aruba's comparative advantage as a destination point in the international financial and convention markets, which includes the definition of requirements for high-technology and other services." (UNDP 1996, p. 3).

In terms of social development and environmental resource management, the UNDP (1996) also indicated that more policy efforts were required for strengthening income equality, labor force participation, human resource development in order to have "the population participate more equitably in the benefits of the economic expansion of the past nine years" (UNDP 1996). With reference to the environment, the UNDP indicated:

\begin{abstract}
"The predominant role of tourism and of the oil industry in the economy of Aruba make imperative the careful management of natural resources based on proper environmental planning. UNDP will assist the Government in preparing an environmental master plan, based on an assessment carried out by the United Nations Environment Programme in February 1995. UNDP will assist the Government in building up national capacity in physical planning and environmental management." (UNDP 1996, p. 4)
\end{abstract}

Although these plans never crystalized, several years later in 2003, the National Tourism Council (NTC) was institutionalized by the Government of Aruba and tasked with the development of a new tourism master plan for the future of Aruba. Accordingly, the NTC (2003):

"...embodied the commitment to the industry to involve both the public and the private sectors in working together to implement strategic changes in Aruba's development, and to build and maintain the island's future as a prime Caribbean destination". (NTC 2003, p. 4)

The NTC involved different destination stakeholders and (public and private) institutions, and identified four key tourism challenges, including (a) the sustainable development for culture, heritage, and environment, (b) quality assurance, standards, and training needs, (c) safety and security for residents and tourists, and (d) the development of a collaborative public-private sector partnership. In recognition of the rapid tourism growth after 1986 and consistent with the previous conclusions by the UNDP (1996), the NTC (2003) indicated:

“...the concerns expressed [...] are of relatively longstanding in Aruba. Others have arisen in the aftermath of the threefold expansion of tourism in the late 
1980s. The latter was accompanied by high levels of new immigration to the island and the accelerated growth of population, leading to urban sprawl, and increasing erosion of the island's natural landscape - primarily adjacent to the island's tourism corridor and Oranjestad. Aruba already has one of the highest densities of tourism and population in the Caribbean.

Although questions of sustainability are often relegated to 'over the horizon', the fact that the island is so small, and the pace of growth so fast, requires that long term constraints - those that are likely to greatly impact present residents and their children - are identified and incorporated into the framework". (NTC 2003, p. 7)

Void of implementation and realization, many of these NTC concerns and thoughts resonated strongly in the subsequent national plan for sustainable development 'Nos Aruba 2025' (In English: Our Aruba 2025) that was developed during the late 2000's by means of a national community-based participatory planning process. Several thousands of residents of different backgrounds and affiliations were actively involved by means of an appreciative inquiry process through which aspirations and pathways for sustainable development were collaboratively designed. The national plan, however, was never adopted and largely abandoned by 2010 after the government and parliamentary elections in 2009.

In 2011, the ATA was privatized as an independent entity ('sui generis') and tax reforms were introduced, including the re-allocation of room tax revenues (previously government tax revenues) to finance the ATA's institutional and promotional activities in developing full-fledged and self-sufficient tourism destination marketing and management organization. Furthermore, the Aruba Tourism Product Fund was established to expand tourism infrastructures. In 2011, the Government of Aruba presented a strategic plan for the development of tourism echoing many of the sentiments presented in previous master plans:

"The objective of this new plan is to maintain and improve Aruba's competitive position in the Caribbean in the short, medium to long term. Additionally, this strategic plan will assist Aruba in generating sustainable growth in the tourism sector in a socially acceptable, environmentally sound and economically viable manner. The outcome of the plan will allow the Government and the private sector to make clear policy choices and commit to a development strategy for tourism, while securing and enhancing the quality of life of its citizens.

The plan is needed for several reasons. While it is known that tourism will continue to play a critical role in the economy of Aruba, the question lies if the current model of tourism specialization that has been used in the past will work in the future. Additionally, changing demographics of tourists have strong implications in understanding the visitor experience to Aruba." (Government of Aruba 2012, p. 11)

Today, the Aruban economy is almost exclusively dependent on tourism as its main economic activity and income, with more than $80 \%$ of GDP generated directly and indirectly from tourism. Annually, the mature and highly tourism-dependent economy generates an estimated US\$ 2 billion from more than two (2) million stay-over and 
cruise visitors, with one of the highest tourism intensity and density ratios in the Caribbean. The tourism industry employs well over one third of the workforce and is a significant source of tax revenues, surging after institutional privatization (in 2010) by an estimated $95 \%$ to well over an estimated US\$ 45 million per year (CBA 2019).

In reflecting on the fundamental changes in travel and tourism that have transpired over the past decade, and in consultation with community stakeholders, the ATA in their Aruba Destination Development Plan (2019) concludes:

“These transformations, coupled with the fact that Aruba's tourism product has reached a state of maturity, means it was time to reflect on what it has achieved over the past decades and look ahead to where it wants to go in the future.

A small island destination greatly dependent on tourism requires a forwardthinking destination development plan. This will:

- fortify its foundation to continue to thrive as a tourism destination for the years and generations to come.

- help balance external factors and conserve its scarce and fragile natural resources.

- safeguard the Aruba way of life and happiness of its people.

- prioritize sustainable tourism practices and the United Nations 2030 agenda, Sustainable Development Goals (SDGs) at national level." (Aruba Destination Development Plan 2019, p. 2)

Nonetheless, future tourism growth is expected to surpass 3 million visitors by 2030 with the continued expansion of tourism accommodations, infrastructures and services, amounting to a total estimated 20,000 accommodations and a tourism workforce expansion of at least 16,000 new labor employment by 2030 (Aruba Gateway 2030 2018; Government of Aruba 2017). In anticipation of this new tourism growth wave and the implications thereof, the AHATA indicates:

"The Aruba Hotel \& Tourism Association advocates for controlled growth and for the government to work urgently with the private sector on a plan for the increased need for staff (which should include a well thought-through migration plan), education, the effects on all infrastructure, and healthcare, etc. Committees are being formed to address these issues in time. We also need to make sure we manage where growth takes place and the location of activities and attractions, to avoid saturation of high-traffic areas. It is and should be our highest priority to ensure that the visitor experience remains enjoyable and return-worthy" (Dobson 2020, p. 2).

Whereas 'the One Happy Island' brand may conjure up images of socioeconomic wellbeing, initial investigations indicate that tourism may have reached or surpassed its optimum growth. In the past, several policy notes and studies have questioned how far and fast tourism can and should expand in Aruba (Cole and Razak 2009; Government of Aruba 2012; IMF 1997; NTC 2003; Peterson 2006; UNDP 1996). More recently, studies suggest that Aruba is experiencing a 'tourism exhaustion' effect (IMF 2019), in which tourism growth is no longer delivering value-added with diminishing economic returns. Research shows that social and ecological disparities have increased in Aruba 
and the community is experiencing significant negative tourism impacts, including growing concerns over environmental pollution and destruction, the loss of quality of life and income equality, in addition to over-construction and crowding, which cumulatively have resulted in a growing animosity toward tourism and further tourism growth (Peterson et al. 2020). In similar vein, the government of Aruba in their economic policy 'A Strong and Resilient Economy 2019-2022' concludes:

"We are at the crossroad of important decisions related to the carrying capacity of the island, to balance the need to protect the environment and to create new economic development. The expected increase in the room inventory will lead to more demand for low skilled labor and low salaries. The question remains if the internal labor market is able to absorb this extra demand for low skilled labor without the import of foreign labor. This influx of foreign labor will put extra pressure not only on the labor market, but also on the housing sector, educational system and health care. Given the expected room expansion and its consequences on the livability on the island, the experience of the visitors could be negatively affected and putting at risk not only the whole tourist industry but also the economic development of Aruba." (Government of Aruba 2019, p. 21).

\section{The State of Over-Tourism in Aruba}

Over the past two decades, Aruba's economic growth was mainly driven by tourism and ancillary industries, including restaurant services, real estate, and construction. Tourism dominates both export and import services (+80\%), and foreign-direct investments are mainly driven by tourism and real-estate investments originating from North America (+65\%). Total visitors have doubled in less than 20 years, with tourism labor immigration and population density growing significantly by the turn of the century. The total amount of visitors per capita (tourism intensity) is currently estimated at 17 (up by 5.6 since 1995) with a tourism density of well over 10,000 visitors per $\mathrm{km}^{2}$. Whereas the growth in stay-over visitors dominated between 1980 and 2000, total cruise visitors and the cruise intensity (cruise-to-stayover visitor ratio) have surged over the past two decades (see Fig. 1).

From an international tourism demand perspective, the segmentation of tourism (origin) markets also witnessed a marked shift over time. Whereas the North American visitor market has always dominated international tourism demand (+60\%), analysis indicates that since 1995, Aruba experienced at least two distinct phases of relative expansion and contraction in the segmentation of international tourism markets ${ }^{1}$ (see Fig. 2). The results suggest that the segmentation of international tourism demand is cyclical in nature and follows global economic shifts and shocks (i.e., economic cycles, economic recessions, and economic crisis). Between 1995 and 2004, international tourism market index (TMI) rose from .36 to .55 - higher degree of concentration -, followed by a contraction from .55 to .34 - lower degree of concentration - between

\footnotetext{
${ }^{1}$ The international tourism market index (ITMI) is based on a Herfindahl-Hirschman index of the degree of diversification by origin tourism geographic markets. The lower the ITMI, the higher the degree of tourism market segmentation, thus more diversified and less concentrated (CBA 2019).
} 


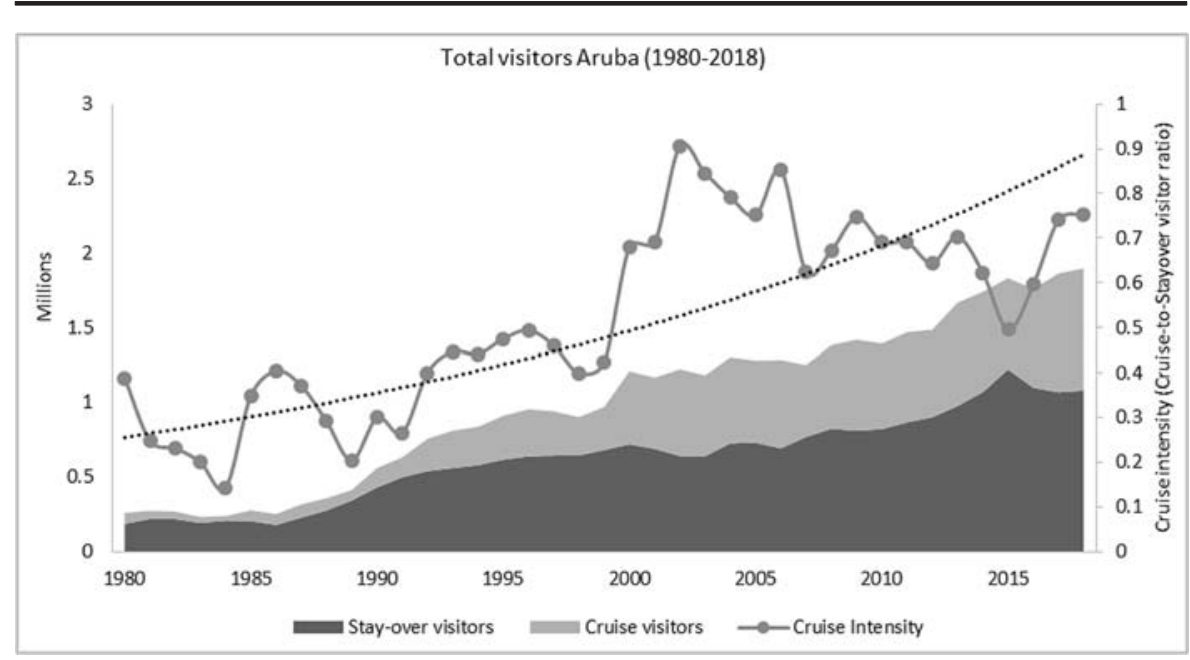

Fig. 1 Total visitors to Aruba 1980-2018 (CBS 2018)

2005 and 2015. Over the past five (5) years, the ITMI rebounded from .37 to .57 , its highest level (of international tourism demand concentration) over the past two decades.

The international tourism demand cycle is largely explained by two complimentary economic forces and cycles across the North American and the Latin American tourism markets (see Fig. 2). Whereas the first tourism market concentration phase was largely driven by the simultaneous expansion in the North American tourism market $(+4.9 \%)$ and the contraction in the Latin American tourism market (-4.3\%), the second tourism market diversification phase was caused by a significant expansion in the Latin American market $(+17 \%)$. During this second phase, growth in the North American tourism demand contracted $(-1.7 \%)$ and the European markets grew $(2.7 \%)$.

The recent rebound in the international tourism demand cycle was primarily driven by the collapse of the Latin American market (-27.6\%; Venezuela in particular), and the strengthening of economic conditions in North America $(+6.1 \%$; especially in the USA). Analysis indicates that while tourism market concentration is positively

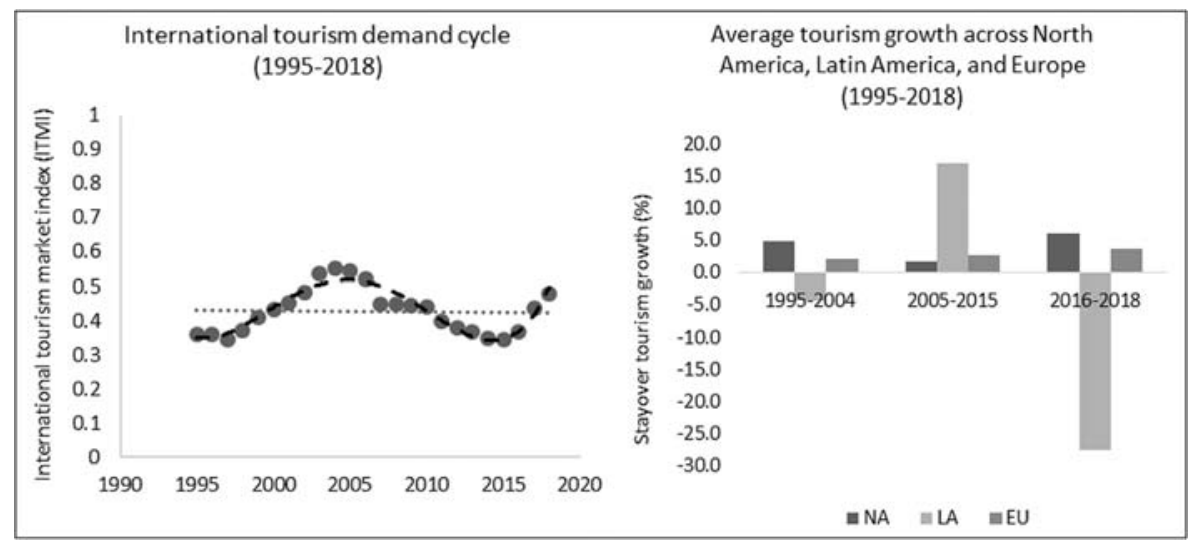

Fig. 2 International tourism demand cycles and tourism market growth (CBA 2019) 
associated with higher tourism intensity $(\beta=13.24 ; p<.01)$, alternatively, the diversification of tourism markets engenders relatively less tourism intensity $(\beta=-16.48$; $p<.01$ ). The findings suggest that not only does surging international tourism demand fuel over-tourism, but more importantly, that the (geographic) segmentation and (stayover vs. cruise) nature of international tourism demand are significant forces that generate over-tourism in select Caribbean SITES.

An unrestrictive principal component analysis with Kaiser normalization and varimax rotation was conducted to identify the main constructs of over-tourism (see Table 2). The analysis yielded five (5) components with satisfactory loadings (>.60), acceptable adequacy $(\mathrm{KMO}>.68$; sphericity $<0.001)$, and reliability (Cronbach $\alpha>$.70) for an exploratory case study. Consistent with previous studies, the findings indicate that the status of over-tourism component incorporates tourism intensity, tourism density, and tourism dependency, reflecting the volume, concentration, and contribution of tourism, respectively.

Three independent constructs - antecedents of over-tourism - were identified, i.e., tourism supply chain, tourism architectural style, and tourism export specialization. Whereas the tourism supply chain component describes the supply chain effect of the growth in airlift, accommodations, and labor, the tourism architectural style component describes the spatial concentration and design of cruise and accommodation

Table 2 Results of principal component analysis

\begin{tabular}{|c|c|c|c|c|c|}
\hline \multirow{2}{*}{$\begin{array}{l}\text { Explanatory } \\
\text { variables }\end{array}$} & \multicolumn{5}{|c|}{ Components } \\
\hline & $\begin{array}{l}\text { 1. Over- } \\
\text { tourism } \\
\text { state }\end{array}$ & $\begin{array}{l}\text { 2. Tourism } \\
\text { ecological } \\
\text { stress }\end{array}$ & $\begin{array}{l}\text { 3. Tourism } \\
\text { supply } \\
\text { chain }\end{array}$ & $\begin{array}{l}\text { 4. Tourism } \\
\text { architecture } \\
\text { style }\end{array}$ & $\begin{array}{l}\text { 5. Tourism } \\
\text { export } \\
\text { specialization }\end{array}$ \\
\hline Tourism intensity & .85 & & & & \\
\hline Tourism density & .86 & & & & \\
\hline Tourism dependency & .68 & & & & \\
\hline Coastal resort stress & & .96 & & & \\
\hline Coastal visitor stress & & .93 & & & \\
\hline Coastal pollution & & .85 & & & \\
\hline Resort density & & & .89 & & \\
\hline Airlift & & & .92 & & \\
\hline Migrant stock & & & .81 & & \\
\hline Cruise intensity & & & & .91 & \\
\hline Resort style & & & & .89 & \\
\hline Coastal length & & & & .61 & \\
\hline $\begin{array}{l}\text { Tourism export } \\
\text { specialization }\end{array}$ & & & & & .91 \\
\hline Trade openness & & & & & .86 \\
\hline Eigenvalue & 7.11 & 2.36 & 2.06 & 1.5 & 1.08 \\
\hline Variance (cumulative \%) & 44.5 & 59.3 & 72.1 & 81.5 & 88.2 \\
\hline $\begin{array}{l}\text { Internal consistency } \\
\quad(\text { Cronbach } \alpha)\end{array}$ & .71 & .89 & .84 & .73 & .79 \\
\hline
\end{tabular}


infrastructures in a specific geographic area or coastal zone. The tourism export specialization component describes the outward (export-led) economic orientation and tourism specialization focused on, e.g., tourism investments and expansion, export earnings and revenues, and promotion. The tourism ecological stress component consists of coastal resort stress, coastal visitor stress, and coastal pollution, and is an indirect effect of over-tourism. It describes the stressors and pressures from land- and marine-based tourism activities in (concentrated) coastal areas, which are conducive to ecological decay and coastal erosion.

Regression analysis was conducted on the state of over-tourism and the previously identified components (see Table 3). A one-year over-tourism time-lag was included as a control variable. In addition, the degree of international tourism segmentation was used as a proxy indicator for the effect of international tourism demand. The results indicate that all four (4) components are significantly related to the state and development of over-tourism in Aruba (adjusted $\mathrm{R}^{2}=0.90 ; p<.05$ ). A positive relationship is found for tourism supply chain $(\beta=.61 ; p<.01)$, tourism architectural style $(\beta=.59$; $p<.05)$, and tourism export specialization $(\beta=.15 ; p<.05)$. Conversely, international tourism market segmentation is negatively associated with the state of over-tourism $(\beta=-.51 ; p<.05)$, i.e., higher tourism market diversification is associated with less intense over-tourism. In general, the results are in line with previous studies and suggest that multiple supply and demand forces shape the propensity for over-tourism in Aruba. More importantly, the results show there is an aggregate effect of interdependent domestic institutional factors that fuel the overrun of tourism.

In terms of the economic contribution of tourism, the findings indicate that whereas nominal tourism service exports experienced significant growth over the past 20 years $(+5.7 \%$ per year), average real tourism receipts growth diminished between 2000 and 2018 ( $-1.5 \%$ per year). Since 2006 , the price index for the domestic tourism industry surged by an estimated 45\% (CBS 2019). Analysis indicates that increasing levels of over-tourism between 1990 and 2018 are negatively associated with real tourism receipts per visitor $\left(\beta=-1.03\right.$; adjusted $\left.\mathrm{R}^{2}=.89 ; p<.01\right)$. The findings show that over-tourism has a negative impact on real tourism receipts per visitor, with a tourism overshoot - beyond the over-tourism vertex - of +3.1 visitors (see Table 4 ).

Although negative, the findings indicate that over-tourism has no significant bearing on real tourism receipts per capita $\left(\beta=-0.10\right.$; adjusted $\left.\mathrm{R}^{2}=.07 ; p>.10\right)$, which decreased by $8 \%$ between 2000 and 2018 . From an economic perspective, the findings suggest diminishing marginal returns from tourism specialization and growth

Table 3 Antecedents of over-tourism in Aruba (1990-2018)

\begin{tabular}{llll}
\hline Independent components & \multicolumn{2}{l}{ Dependent component: Over-tourism state } \\
\cline { 2 - 4 } & Coefficient $(\beta)$ & t-test & Significance $(\mathrm{p})$ \\
\hline Tourism supply chain & .61 & 2.82 & $<.01$ \\
Tourism architectural style & .59 & 2.51 & $<.05$ \\
Tourism export specialization & .15 & 2.05 & $<.05$ \\
International tourism segmentation & -.51 & -2.47 & $<.05$ \\
Adjusted $\mathrm{R}^{2}$ & .90 & & \\
\hline
\end{tabular}


Table 4 Results of regression and vertex analysis

\begin{tabular}{|c|c|c|c|c|c|}
\hline \multirow[t]{2}{*}{ Dependent variables } & \multicolumn{5}{|c|}{ Independent variable: Over-tourism Control variables: Population and Inflation } \\
\hline & $\begin{array}{l}\text { Coefficient } \\
(\beta)\end{array}$ & $\begin{array}{l}\text { Over-tourism } \\
\text { vertex }(\mathrm{v})\end{array}$ & $\begin{array}{l}\text { Tourism } \\
\text { overshoot }\end{array}$ & Adjusted $\mathrm{R}^{2}$ & Significance $(\mathrm{p})$ \\
\hline Output volatility & .24 & 13.1 & +3.8 & .58 & $<.05$ \\
\hline Real tourism receipts/visitor & -5.04 & 13.8 & +3.1 & .36 & $<.05$ \\
\hline Visitor satisfaction & -1.2 & 12.2 & +4.7 & .87 & $<.05$ \\
\hline Labor force participation & -.50 & 14.4 & +2.5 & .87 & $<.05$ \\
\hline Income inequality & 1.31 & 13.1 & +3.8 & .81 & $<.05$ \\
\hline Fiscal costs & 1.53 & 13.7 & +3.2 & .58 & $<.05$ \\
\hline Ecological stress & 4.74 & 13.3 & +3.6 & .74 & $<.05$ \\
\hline
\end{tabular}

after 2000. Similarly, after experiencing a significant tourism boost during the 1990s, Aruba's economy stagnated with a structural weakening of real growth (from $6.4 \%$ to $1.3 \%$ ) over the past decade. The long run real economic growth is currently projected at $1.1 \%$ (CBA 2019). The overdependency on tourism exports is also demonstrated by the increasing output volatility from $2.8 \%$ to $4.3 \%$ between 1990 and 2018 . The results suggest that over-tourism is a significant source of rising output volatility $(\beta=.24$; adjusted $\left.\mathrm{R}^{2}=.58 ; p<.05\right)$.

Conversely, available visitor satisfaction survey data (CBS 2016a, 2016b, 2016c) reveals that over-tourism is negatively correlated with visitor satisfaction and perceived quality of tourism services. The findings suggest that visitors are increasingly dissatisfied with the destination's cleanliness $(-40.8 \%)$, hospitality and friendliness $(-26.5 \%)$, and local transportation $(-12.6 \%)$, which may explain the decline in real tourism receipts growth and be indicative of the negative effects and tourism spillovers of environmental pollution, traffic congestion, and workforce exhaustion; on average, there are 35 visitors for every workforce employee.

Since the 1960s, Aruba's population expanded largely due to several industrial waves of labor immigration related to, respectively, the oil refining industry and the tourism industry. It is estimated that at least $45 \%$ of the population is foreign-born, with tourism immigration remittances close to $3 \%$ of GDP (CBA 2019). Over the past five decades, the working age population surged with employment more than doubling and largely concentrated $(+70 \%)$ in five (5) sectors: tourism services, wholesale and retail, real estate and renting, construction, and public services. However, despite labor force expansions, labor productivity and labor participation rates have deteriorated significantly over the past decade, dropping by an estimated 12 percentage points from $70 \%$ to 58\% (CBS 2019). Consistent with the decline in real tourism receipts per capita and real GDP per capita, labor productivity also regressed between 2000 and 2018. Regression analysis indicates that over-tourism has a negative impact on labor force participation and a tourism overshoot of +2.5 beyond the over-tourism vertex (see Table 3).

Analysis shows that tourism labor wages lag average median wages by at least $10 \%$ for almost a decade. Income inequality as measured by the Gini coefficient rose from 
.38 to .46 between 1995 and 2018, indicating a relative deterioration of income equality. The findings show that over-tourism has a significant impact on income inequality $\left(\beta=1.31\right.$; adjusted $\left.\mathrm{R}^{2}=.81 ; p<.05\right)$. Real wages have remained stagnant across income distribution for over a decade, which corroborates the earlier finding on stagnant real GDP per capita growth. The level of vulnerable employment, measured by the relative poverty threshold of $60 \%$ of the median income, deteriorated between 2000 and 2018, especially in the hotel, restaurant, and construction industries (CBS 2018). Moreover, an estimated $40 \%$ of households are financially overleveraged and indebted (CBA 2019). Regression analysis indicates that over-tourism has a negative impact on income equality and a tourism overshoot of +3.8 (see Table 4).

In confronting the increasing levels and challenges of social disparities and inequality, the Government of Aruba launched a special 'social crisis' program in 2019 (Government of Aruba 2019), yet faced challenges in financing the program due to limited fiscal space; the debt-to-GDP ratio rose from $39 \%$ to an estimated $75 \%$ between 2000 and 2018 (CBA 2019). From a tourism perspective, the tourism exports-to-debt ratio is projected at $96 \%$, which signals significant fiscal vulnerability. Thus, despite significant tourism investments and growth over the past decade, fiscal space and social wellbeing have steadily deteriorated.

Furthermore, analysis shows that tourism growth and intensity are positively associated with government expenditures between 1995 and 2018 in Aruba. The results suggest that over $50 \%$ of the surge in government expenditures over the past two decades is (indirectly) related to over-tourism $\left(\beta=1.53\right.$; adjusted $\left.\mathrm{R}^{2}=0.58, p<.05\right)$. These cost effects ensue, however, with a time lag of at least five (5) years. Thus, while the (tax revenue) benefits of tourism growth are recorded within fiscal years, the (government) expenditures of over-tourism emerge over an expanded period of time, oftentimes accumulating over generations and spanning several government cycles. In the case of Aruba, negative fiscal externalities of over-tourism emerged after the turn of the century and continue to 'slow burn' an already restrained fiscal space and limiting fiscal buffers against external economic shocks and internal social vulnerabilities.

Furthermore, the re-allocation of room tax revenues - from government tax income to tourism tax income - also weakened the fiscal budget after 2011. Recent evidence suggest that over-tourism may also have an indirect long-term impact on the cost of doing business and cost of living due to relatively high levels of employers' social contribution and (core) inflation, which gradually arise from the need to recover 'hidden' fiscal costs and minimize (structural) fiscal deficits (CBA 2019).

With reference to Aruba's tourism infrastructure, the tourism industry is largely clustered along the northwest coastline with an estimated 860 rooms per $\mathrm{km}^{2}$; a significant expansion $(+103 \%)$ in less than two decades (see Fig. 3). Although a small island, other geographic districts in Aruba remained relatively void of (large scale) tourism-related activities and infrastructures between 1995 and 2019. The tourism industry zone was established during the late 1980's and represents an estimated $16 \%$ of the island's total geography. Today, there are an estimated 14,000 accommodation units, including hotel and time share resorts in addition to condominiums, villas, and guest houses as well as (more geographically dispersed) rental apartments. Whereas the expansion in hotel and time share rooms drove the surge in accommodations up until the early 2000's, over the past decade, accommodation growth was largely spurred by the construction of condominiums, guesthouses, and 
Growth in accommodation types and total rooms (Aruba, 1960-2020e)

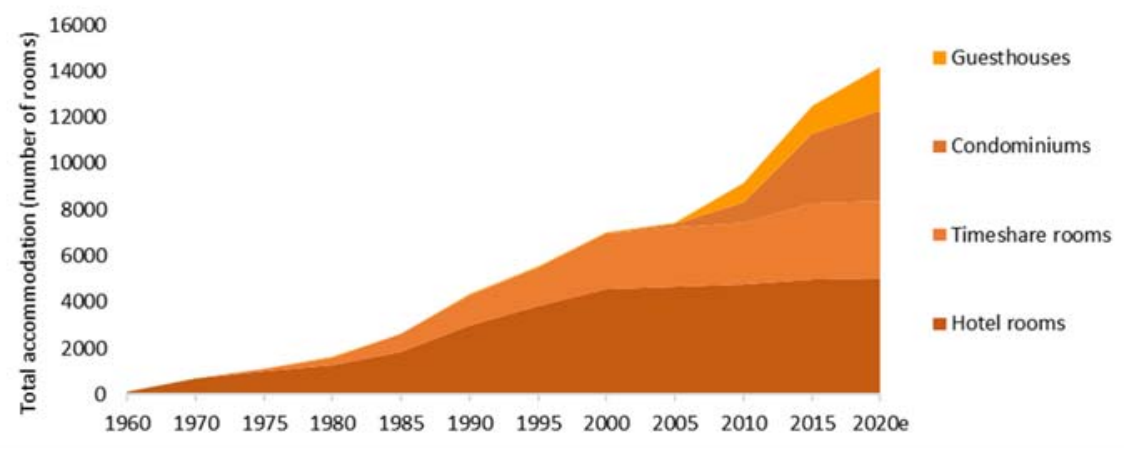

Fig. 3 Growth in accommodation types and total rooms

rental apartments $(+51 \%)$, which increased the (pre-existing) infrastructural pressures and coastal resort density levels.

Regression analysis was conducted to assess the relationship between the state of over-tourism and tourism ecological stress. The findings show a significant curve-linear relationship between the state of over-tourism and tourism ecological stress $(\beta=4.74$, adjusted $\left.\mathrm{R}^{2}=0.74, p<.01\right)$. This concave relationship indicates that as the intensity and density of tourism increases, the ecological pressures grow and, more importantly, accelerate after exceeding a critical threshold. Over-tourism is associated with significant ecological pressures and a tourism overshoot of +3.6 beyond the over-tourism vertex (see Table 3 ). These findings suggest that over-tourism is partially responsible for the structural decay and loss of ecological services, which is currently valued at an estimated $10 \%$ of GDP. Although regional zoning and marine conservation plans were adopted in 2019, Aruba's natural habitats and marine environment have remained unprotected for well over 100 years since the exploitation of the phosphate, gold, and oil refining industry during the 1920's, and the subsequent construction and expansion of large scale tourism infrastructures and urbanization since the late 1970's (CBS 2016a, 2016b, 2016c).

These enduring ecological pressures are also intertwined with changes in climate and nature. In terms of temperature, available evidence indicates that the sea water temperature has slowly risen over the past 60 years. It is estimated that sea water temperatures have increased with at least $+1.3 \mathrm{C}$ since the 1950's (CBS 2016a, 2016b, 2016c). Available energy consumption records between 1981 and 2016 indicate that the effect of rising average temperatures is also reflected in the increase of average energy consumption per household (adjusted $\mathrm{R}^{2}=0.37 ; p<.10$ ) and the rise in relative household energy consumption expenses from 4.8\% (in 1981) to 10.8\% (in 2016). Despite the increasing renewable energy production $(+17 \%)$, household energy consumption has also risen, which suggests that persistent household energy consumption behaviors are at play in Aruba. Further analysis found no significant relationship between increasing temperatures and real GDP per capita $(p>.10)$.

Available data suggests that the slow burn effect of temperature rising is reflected in increasing incidences of coral bleaching along Aruba's coastal reefs over the past 
decade. In combination with the structural deforestation and dredging of marine and coastal ecologies (i.e., coral reefs, mangroves, palm trees, etc.) since the late 1940's, the slow and consistent rise in seawater temperature is likely also responsible for the loss of marine life and marine biodiversity (CBS 2016a, 2016b, 2016c). Moreover, although no significant historical data is available, the growing stress on the local marine ecosystem is also due to the incessant acidification of marine waters - resulting from past oil spills and leakages, polluted water runoff, and the non-treated coastal disposal of waste - as well as the growing population density and surging coastal urbanization (CBS 2016a, 2016b, 2016c).

The emission of carbon dioxide is an additional component in the rise of temperatures, energy consumption, and environmental decay. Historical archives show that between 1970 and 2012, the carbon intensity rose sharply to well over 2500 million mT $\mathrm{CO}^{2}$ in Aruba. This significant level and surge stemmed largely from four factors, i.e., (a) an energy supply based on fossil fuels (HFO: heavy fuel oil), (b) the operation of the oil refinery, (c) the expansion in tourism infrastructures and services, and (d) the subsequent growth of the labor force, the population, and the residential urbanization. With the closure of the oil refinery in 2012 and the push for renewable energy adoption, $\mathrm{CO}^{2}$ emissions dropped significantly $(-65 \%)$ by 2016.

In addition to carbon emissions, energy intensity is also a significant source of $\mathrm{CO}^{2}$. Energy intensity emanates largely from private and public service infrastructures, including residential and commercial buildings, and business and civil services. Thus, beyond energy supply, energy consumption behaviors are also integral to carbon emissions. Based on an analysis of two proxy indicators for energy-based $\mathrm{CO}^{2}$ emissions, i.e., real private consumption and energy consumption, the results show that similar to the rise in carbon intensity, the energy intensity increased significantly $(+86 \%)$ in Aruba. The surge in energy consumption stems largely from the growth in tourism during the 1990s and the subsequent population expansion and urbanization. This overrun of tourism growth explains at least three quarters of the surge in carbon emissions and energy intensity $\left(\beta=0.26\right.$; adjusted $\left.\mathrm{R}^{2}=0.81 ; p<.05\right)$ over the past two decades. However, unlike the reduction in carbon intensity in recent years (2012-2016), energy intensity remained relatively stable.

With reference to extreme weather events, analysis indicates that prior to the $1950 \mathrm{~s}$ hurricanes and major tropical storms would graze the island every 75 to 80 years. Over the past five decades, the time interval between extreme weather events has shortened considerably to an estimated 6 to 8 years. Extreme weather events over the past 20 years coincide with major hurricanes and tropical storms in the Caribbean, including e.g., Joan (1988), Bret (1993), Lenny (1999), Ivan (2004), Felix (2007), Omar (2008), and Matthew (2016). Whereas Aruba was not in the direct path of these hurricanes, the subsequent precipitation and storm surges caused significant flooding with average rainfalls of $795 \mathrm{~mm}$; almost treble the annual average of $274 \mathrm{~mm}$ in Aruba. Conversely, the findings indicate the occurrence of several periods of drought after the turn of the century.

In general, the results suggest an increase in climate volatility with relatively more extreme weather patterns - involving both extreme precipitation and extreme drought emerging over the past two decades. National census records (CBS 2016a, 2016b, $2016 \mathrm{c}$ ) indicate that over the past two decades, incidents of residential and commercial flooding have indeed increased substantially $(+82 \%)$. Findings from spatial data 
analysis show that an estimated $46 \%$ of all households are located in coastal residential areas with density levels well over 1200 residents per $\mathrm{km}^{2}$ as well as at least 10,000 tourists per $\mathrm{km}^{2}$ (CBS 2016a, 2016b, 2016c). These coastal areas are also prone to beach erosion due to their predominantly low elevation $(<5 \mathrm{~m})$ and limestone geological configuration, which is susceptible to ocean acidification, pollution, and carbon emissions.

To summarize, based on the overall results of this study, the following conceptual model is proposed that captures the dynamics and flow over-tourism in terms of antecedents and effects, and their interdependencies (See Fig. 4). As an initial step towards a more comprehensive theoretical framing of over-tourism (in Caribbean SITES), the conceptual model consists of nine different constructs depicting (a) three (3) independent institutional drivers of over-tourism, (b) the mediating over-tourism construct, and (c) three (3) dependent impact constructs. Furthermore, two (2) exogenous constructs capture the external shifts, shocks, and market demand that moderate the state of over-tourism.

The extended theoretical framing of over-tourism proposes that there are several institutional forces that exert significant positive political-economic pressures on the propensity for over-tourism in a non-sovereign Caribbean SITE, i.e., a neo-liberal outward-oriented tourism policy focused on export specialization, supply growth, and large-scale infrastructure expansion, which are largely based on private and political interests to the exclusion of societal values and community interests. The results corroborate previous studies and demonstrate the political and historical workings of several institutional failures and legacies involving, e.g., rent-seeking behaviors, market-driven interests, coercive community participation, and increasing structural deficits in regulation, regulatory enforcement, sound governance, participatory decision-making, and community empowerment. For over two decades, the systemic exclusion of the local community and the structural disregard for the destination's socio-ecological capabilities have led to significant policy drift, growing community

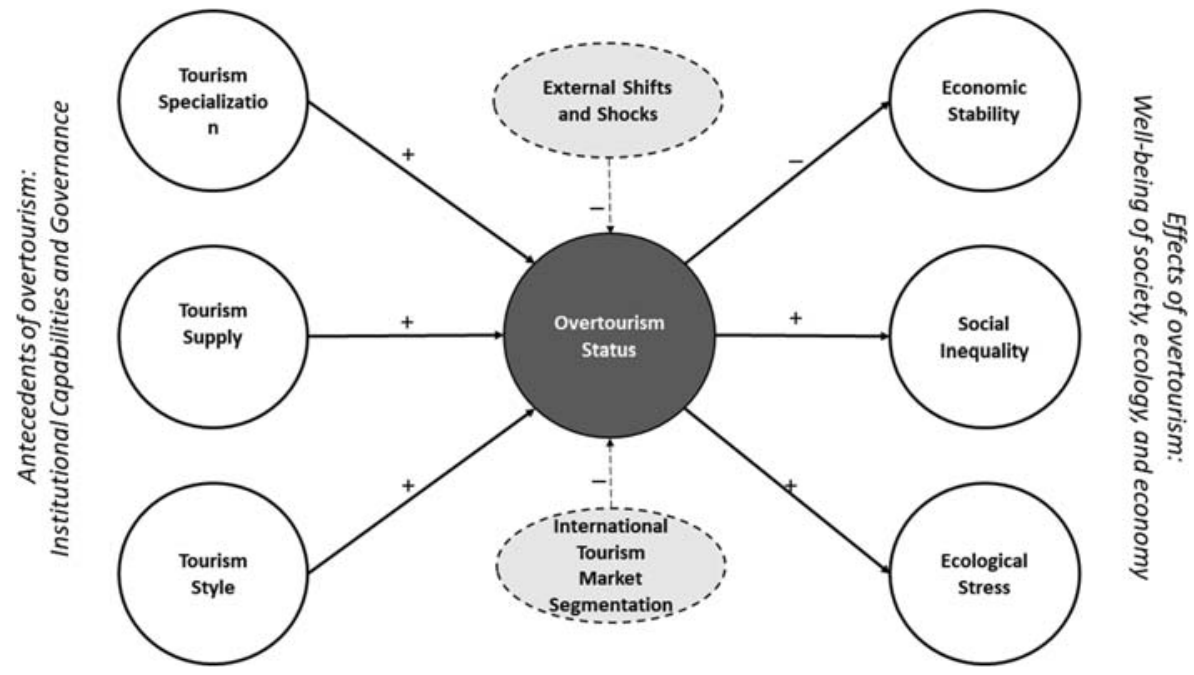

Fig. 4 Conceptual model: extended theoretical framework of antecedents and effects of over-tourism in Caribbean SITE 
apathy, increased social inequality, rising ecological stress and environmental destruction, and growing fiscal pressures and economic instability.

\section{Conclusion}

This study addressed the political economy of over-tourism in a non-sovereign SITE and discussed a historical case study on the evolution and socio-ecological impacts of tourism growth in Aruba. The aim of the in-depth case study was to explore the main antecedents, processes, and effects of over-tourism, and contribute to a more comprehensive and contextualized understanding of the complexity and dynamics of overtourism within the context of a contemporary small island community in the Caribbean. While limited to a single case study, the findings provide an extended conceptualization and framing of over-tourism from a small island Caribbean perspective, which emphasizes the political, institutional, and historical forces that shape tourism policies and development.

In reviewing the overall findings of this study, the general results corroborate previous research on the adverse relationship between over-tourism, community wellbeing, and economic development. More specifically, the research demonstrates that an aggregate of political economic forces that shape and generate over-tourism over time and space. The results indicate that there are three main institutional factors that engender a state of over-tourism, which are primarily shaped by public and private sector growth-lead strategies. These institutional factors are tourism export specialization, tourism supply chain, and tourism architectural style. Furthermore, the findings indicate that tourism market demand and diversification restrain the propensity for over-tourism. Thus, both tourism supply and tourism demand actively influence and shape the evolution of over-tourism.

More importantly, in stretching the concept of over-tourism to reflect the political economic role of tourism in a Caribbean SITE and the subsequent institutional overpowerment of the destination community - de facto community exclusion and disempowerment in tourism decision-making and development -, the findings yield strong evidence that there is more to over-tourism than simply an over-shoot of tourism growth. Essentially, over-tourism is a manifestation of coercive institutional powers and processes, and represents the social overpowerment or disempowerment of a destination community's agency. From a political-economic perspective, the results show how the institutional capture of tourism-centric values and voices, and a confluence of institutional, market, and policy failures have systematically and structurally shaped the growth and growing adversities confronting the local community in a nonsovereign Caribbean SITE.

In the specific case of Aruba, the findings indicate that this 'One Happy Island' has faced substantial tourism policy drift since the development of the initial tourism master plan in the 1960's. Despite numerous tourism policies and master plans, and the relatively consistent policy intent - spanning well over five decades - on, e.g., sustainable development, quality assurance and training, safety and security, quality visitor experiences, environmental quality, social equality, and economic viability, the realization of these master plans has, nevertheless, resulted in a system of tourism specialization, supply, and style that is disconnected from society and the local 
community. The resulting policy ambiguity, economic disconnectedness, social inequality, and ecological degradation have engendered significant socio-ecological vulnerabilities, which have resulted in increasing community disengagement and discontent with tourism.

These findings support previous studies that indicate that social inequality, ecological degradation, and economic instability are likely to coalesce. Social inequality erodes community well-being and institutional trust, and engenders ecological degradation due to both environmental resource competition in addition to weakening the social foundations that underpin the requisite civic and community actions to enact and enforce environmental regulation. The resulting extractive institutions and the erosion of the socio-ecology nurtures the concentration of resources and power, thereby generating economic instability, volatility, and more fragile community development to the detriment of community well-being.

Although restricted to a single in-depth case with limited generalizability, the extended conceptualization and Caribbean framing of over-tourism provide several avenues for future research. An investigation of multiple case studies across the Caribbean, especially in sovereign and non-sovereign SITES, would provide further evidence and validation for the institutional forces that shape over-tourism, and the potential adverse impacts on community well-being. Likewise, it would be relevant to scrutinize these propositions from a continental, metropolitan or city perspective, particularly as the rise of over-tourism is a global phenomenon and certainly not confined to the Caribbean. Moreover, contingent upon sufficient reliable data, the application of econometric analysis would provide further empirical scrutiny of the proposes conceptual model and hypotheses, especially in terms of reverse causality.

Future research could also consider examining a possible self-reinforcing effect - a positive feedback loop - of over-tourism on institutional forces that generate an overtourism path dependency, i.e., rising levels of tourism intensity beget increased tourism specialization and tourism supply expansion, akin to a tourism 'lock-in' effect or 'entrapment' due to past tourism performance and success. This institutional capture stimulates tourism myopia and a short-term tourism growth orientation, which causes a gradual tourism overshoot of socio-ecological ceilings with significant costs in the medium to long term. Because these costs and negative spillover effects remain relatively concealed for an extended period of time - beyond political economic cycles -, they are often not considered or disregarded in tourism governance and policies, thus setting the scene for community disenfranchisement and future disasters.

Acknowledging the delimitations of this study, the findings hold several policy implications for strengthening the resilience of Caribbean SITES in the wake of overtourism and community overpowerment. First and foremost, the findings testify to the contextual, historical, and institutional nature of over-tourism, and more importantly, to the need to address social, political, and ecological developments explicitly, extensively, and urgently in national policies and institutional arrangements, especially in nonsovereign and tourism-dependent small island economies in the Caribbean. Rather than simply devise buffers for absorbing shocks and bounce back to previous dependent paths of economic and social decay, fostering the resilience of Caribbean SITES requires building institutional capabilities to anticipate shocks, to adapt and learn, and bounce forward towards new pathways of development. There is, however, no silver bullet solution to the challenges of over-tourism. 
One of the biggest risks to Caribbean SITES is underestimating the adverse effects of over-tourism and downplaying the risks of climate change, i.e., tourism myopia compounded by willful ignorance. Resolving the challenge of over-tourism requires first and foremost - an acknowledgement of the societal costs and moral risks associated with the uncontrolled and unregulated expansion of tourism; especially when considering the many policy studies and recommendations that have been produced and published over the past 50 years, in addition to the increasing impact of climate change. While some Caribbean SITES may have been able to afford some degree of policy drift and institutional inertia in the past, today climate change and related anthropogenic challenges are demanding nothing less than a fundamental rethink and redirection. Echoing the sentiments of the United Nations more than a decade ago, if Caribbean SITES countries fail to adapt, they are likely to take direct and substantial hits with detrimental repercussions for lives and livelihoods.

More specifically, there is an increasingly urgent need to transition away from traditional, uncontrolled, and exploitive tourism growth fetishes towards transformative, resilient, and inclusive development. This structural transformation reflects the redesign of constricted, short-term, market-based, and elitist policies, which is based on the resourcefulness and values of a destination's community and citizens. The structural transformation describes the transition towards a community-driven development by building capabilities for innovation, internalization, and institutionalization for strengthening the resilience of small island tourism development in the Caribbean (See Table 5).

Pathways for innovation are primarily intended to mitigate the community and climate risks of tourism specialization, single-market supply dependencies, and expansive infrastructure and hotel construction footprints; in effect, the main drivers of overtourism (See independent constructs in Fig. 4). Policy recommendations include the diversification of the economy and tourism markets, in addition to developing new community-driven and culturally-authentic niche products, experiential services, and micro-businesses. With its rich history and culture in cuisine representing well over 90 nationalities as well as an embryonic Caribbean artistic scene, culture and creativity would provide a new opportunity for local entrepreneurs and the community in the specific case of Aruba. Likewise, wellness and health as an extension for organic foods and pristine ecology, would provide a viable avenue to explore by the community and social entrepreneurs. This would also stimulate the strengthening of domestic agri-food chains as well as the adoption of circular business models to improve resource efficiencies (for, e.g., energy, water, waste, land). Likewise, reskilling of the workforce and the creation of new professional education programs would engender a knowledgebased, community-driven generation of tourism entrepreneurs, professionals, and policymakers.

Whereas innovation pathways are necessary, they are, however, insufficient for mitigating the socio-ecological risks of over-tourism. Hereto, the costs and adverse impacts of over-tourism would need to be incorporated and 'internalized' into tourism governance and development. To complement the conventional 'outward-oriented' tourism policies and (growth) metrics, public officials and tourism authorities need to focus on 'internal-oriented' community development and commensurate (socioecological) metrics (See dependent constructs in Fig. 4). The pathways for internalization describe the explicit recognition, interrelationships, and resourcefulness of a 
Table 5 Pathways for safeguarding community well-being to strengthen the resilience of Caribbean SITES

Pathways

Innovation

Internalization

Diversify the economy and tourism with new niche-based products and services.

Incorporate circularity and circular economy practices into tourism business models and incentivize corporate social responsibility by the private sector.

Visitor planning and flow management of cruise and stayover visitors to reduce destination seasonal congestion and spatial crowding.

Foster the digitization and digital transformation of tourism and transport service infrastructures.

Promotion and establishment of workforce up-skilling and reskilling programs in public-private partnership (especially targeted at the most vulnerable, notably youth).

Enable local tourism and social entrepreneurship with targeted (micro-credit) financing and funding programs.

Foster community-based and small-scale tourism businesses through micro-enterprising programs. This includes culturally-themed and community-authentic accommodations and restaurants.

Promotion and stimulation of domestic supply chains (e.g., for local food production, arts, culture and other creative industries).

Innovate professional education programs with new mind- and skillsets for (young) tourism employees and entrepreneurs focused on social and innovation competencies for the public and private sector.
Establish and develop a national data system for the structural measurement and monitoring of environmental quality (including marine biodiversity) and social equality (including income inequality, community well-being) to inform tourism decision-making and development (see also National Tourism Council and National Council for Climate Change).

Set up community-based and citizen-driven tourism observatories to monitor visitor behaviors and community sentiments (especially in 'tourism hotspots').

Promote and establish a 'whole of government' platform to fully and transparently engage civic society, community stakeholders, public and private sector.

(Re-) Allocate and earmark tourism tax revenues to national and community education programs.

Develop and implement community advocacy programs to build and strengthen awareness of tourism opportunities and vulnerabilities as well engage and empower civic society in national and regional tourism development.

Stimulate regional and rural community tourism cooperatives with local representatives and stakeholders to involve and engage citizens in community-driven tourism development.

Strengthen institutional capabilities in public-sector and tourism authorities for an inclusive and sustainable development of tourism at the regional and local level.
Institutionalization

Implement environmental regulation and regulatory enforcement of coastal zone conservation and fragile habitats regeneration (spatial zoning for residential and commercial development).

Establish national council and policies for climate change resilience and adopt new legislation for infrastructure and building codes.

Incorporate climate change readiness and resilience measures in fiscal, economic, and social policies, and community programs.

Integrate environmental and energy measures into incentives and investment programs to reduce and recycle waste and increase resource efficiency (e.g. energy, water, land, infrastructures).

Labor regulation and regulatory enforcement of (minimum) wages, income equality, and labor force participation (non-informal labor).

Labor market flexibilization should be pursued to foster broader workforce participation and mobility, especially for young(er) professionals.

Regulate accommodation supply, especially of large-scale tourism infrastructures in coastal-sensitive and climate change regional zones.

Destination stewardship and establishment of a National Tourism Council with statutory mandates and inclusion of civic society, community representatives, and non-governmental organizations 
and environmental integrity, including the well-being of society and happiness of communities (Musikanski et al. 2019; VanderWeele 2019).

Pathways for internalization entail the establishment and usage of a national (data) system for measuring and monitoring community well-being and environmental quality in a formal, transparent, and structured manner to enable comprehensive and evidencebased tourism policies and development. Furthermore, regional, community-based, and citizen-driven tourism observatories should be developed and established to monitor visitor behaviors and community sentiments (especially in 'tourism hotspots'). This would foster community engagement and ownership as well as promote a 'whole of government' platform to fully and transparently engage civic society, community stakeholders, public and private sector. Thereto, tourism tax revenues should be (re-) allocated and earmarked for national and community education programs. Community advocacy programs and regional tourism cooperatives should also be considered to strengthen capacity and awareness of tourism opportunities and vulnerabilities.

Innovation and internalization are prone to fade and fumble if not institutionalized. Mitigating the risks of over-tourism and safeguarding community wellbeing, thus, depend on the structural transformation of the localized networks of power and control; de jure and de facto. Notwithstanding the most comprehensive and forward-looking tourism vision, policies, and leadership, in the absence of strong institutions and governance, sustainable development of tourism will remain ephemeral and beyond the reach of Caribbean SITES. Whereas de jure structural reforms are necessary to strengthen the resilience of Caribbean SITES, they are insufficient and are likely to falter when de facto political and institutional reforms are absent. This calls for an almost paradigmatic shift in values, institutions, and governance; a transition that is unlikely to happen in the absence of any significant crisis or 'creative destruction'.

While the former describes continued institutional capture and path dependency, and consequently, the strengthening of existing institutional frames, relationships, and predictable outcomes (e.g., continued construction and expansion of hotel room capacity despite a global pandemic and economic recession), the latter depicts a process of creating new pathways, restructuring institutional frameworks, fostering new and diverse relations, internalizing socioecological values, and stimulating institutional learning (e.g., establishing and enforcing climate-resilient tourism infrastructure regulations, or starting an agri-tourism cooperative in collaboration with rural farmers and providing a digital platform for tracking and tracing supply and quality).

Pathways for institutionalization describe structural reforms and regulatory innovations that engender ethical, transparent, and inclusive governance within the rule of law and the voice of the community. The entails the rethinking and redesigning of institutional foundations and capabilities with strong codes of ethics, competence, integrity, and ingenuity. Thereto, the regulation and regulatory enforcement - with sanctions - of environmental conservation, coastal zonification, and regeneration of biodiverse habitats (e.g., coral reefs, mangrove ecologies, wetlands of endemic species) are a prime directive. Spatial zonification and governance are quintessential for regulatory execution and enforcement. Likewise, establishing environmental oversight and a national council for climate resilience are highly recommended to firmly and legally position matters of nature and ecology on the highest national agenda. Environmental and energy measures should also be integrated into incentives and investment programs 
to reduce and recycle waste and increase resource efficiencies (for, e.g., energy, water, land, infrastructure, and construction).

From a labor and tourism workforce perspective, flexibilization, participation, equality, and mobility should be placed on the national agenda for development. The regulatory enforcement and oversight of minimum wage payments, income equality, workforce registration, and formal labor force participation are key directives for policy execution. Labor market flexibilization should be pursued to foster broader workforce participation and mobility, especially for young(er) professionals and other vulnerable groups in society. Lastly, the statutory establishment of destination stewardship and a national tourism council should be pursued to safeguard community well-being to strengthen the resilience of small island tourism development. Hereto, commensurate institutional capabilities need to be developed with the structural involvement and inclusion of civic society, community representatives, and non-governmental organizations.

To conclude, this study underscores the contextual and dynamic nature of overtourism, and more importantly, the need to address social and ecological developments explicitly, extensively, and urgently in the policies, norms, and institutional arrangements, especially in tourism-dependent small island economies in the Caribbean. Rather than continue on the old path of extractive and exploitive growth, Caribbean SITES need to forge new pathways towards inclusive tourism development and lead from an emerging future of climate change and other geopolitical challenges. Although certainly not an easy feat as witnessed by the enduring and persistent policy and market failures over the past decades, if these principles and fundamentals of sound political and public governance are not cultivated and advanced, no amount of master planning will suffice. Without concerted, committed, and creative institutional actions and agency to nurture the well-being of small island societies, the existential challenges of over-tourism and climate change will endure and gradually intensify in Caribbean SITES. Quintessential is the institutionalized involvement of the community and civic society in order to strengthen the resilience of small island tourism economies in the twenty-first century.

\section{Compliance with Ethical Standards}

Conflict of Interest The author declares no conflict of interest.

Ethics Approval and Consent to Participate The research in this paper did not involve human subjects and thus no consent was required.

\section{References}

Acemoglu, D., \& Robinson, J. A. (2012). Why nations fail: The origins of power, prosperity and poverty. New York: Crown.

Acevedo, S., LaFramboise, N., \& Wong, J. (2017). Caribbean tourism in the global marketplace: Trends, drivers, and challenges. In T. Alleyne, I. Otker, U. Ramakrishnan, \& K. Srinivasan (Eds.), IMF (2017). Unleashing growth and strengthening resilience in the Caribbean. Washington DC: IMF Publications.

Aghion, P., \& Howitt, P. (1998). Endogenous growth theory. Cambridge: Massachusetts, MIT Press.

Aruba Destination Development Plan (2019). Retrieved from: http://www.sustainablesids.org/knowledgebase/ coe-case-study-in-sustainable-development-one-happy-island-working-towards-one-happy-planetlessons-learned-by-the-sdg-commission-of-aruba-2019. Accessed 10 Oct 2019. 
Aruba Gateway 2030 (2018). Retrieved from: https://www.airport-technology.com/projects/queen-beatrixinternational-airport-expansion/. Accessed 4 June 2019.

Baldacchino, G. (2005). Innovative development strategies from non-Sovereign Island jurisdictions? A global review of economic policies and governance practices. World Development, 34(5), 852-867.

Baldacchino, G. (2006). Small islands versus big cities: Lessons in the political economy of small islands. Journal of Technology Transfer, 31(1), 91-100.

Benedict, B. (1967). Problems of smaller territories. London: Athlone Press.

Bishop, M. L. (2010). Tourism as a small-state development strategy: Pier pressure in the eastern Caribbean? Progress in Development Studies, 10(2), 99-114.

Bishop, M. L. (2012). The political economy of small states: Enduring vulnerability. Review of International Political Economy 19(5):1-19

Bosselman, F. (1978). In the wake of the tourist. Washington DC: The Conservation Foundation.

Brautigam, D. \& Woolcock, M (2001). Small states in a global economy. United Nations University, discussion paper no. 2001/37. Helsinki, Finland.

Budowski, G. (1976). Tourism and environmental conservation: Conflict, coexistence, or symbiosis? Environmental Conservation, 3(1), 27-31.

Butler, R. (1980). The concept of a tourism area cycle of evolution: Implications for management of resources. Canadian Geographer, 24(1), 5-12.

Cannonier, C., \& Galloway, M. (2019). The economic growth and impact of tourism in Small Island developing states - evidence from the Caribbean. Tourism Economics, 25(1), 85-108.

Capocchi, A., Vallone, C., Pierotti, M., Amaduzzi, A. (2019) Overtourism: a literature review to assess implications and future perspectives. Sustainability, 11 (12), 3303

Caribbean Tourism Organization. (2019). Caribbean Pushes for Inclusive Tourism Development. Retrieved from https://www.onecaribbean.org/caribbean-pushes-for-inclusive-tourism-development/. Accessed 3 Mar 2020.

Caribbean Tourism Organization. (2020). State of the Tourism Industry 2019. Retrieved from https://www. onecaribbean.org/statistics/annual-reviews-prospects/. Accessed 10 Jul 2020.

Center for Responsible Travel (CREST) (2018). The Case for Responsible Travel: Trends \& Statistics 2018. Retrieved from https://www.responsibletravel.org/docs/ The_Case_for_Responsible_Travel_2018_ FINAL_FOR_WEB.pdf. Accessed 2 June 2019.

Central Bureau of Statistics. (2016a). Inconveniences in the home neighborhood in Aruba. Retrieved from $\mathrm{http}: / / \mathrm{cbs} . a w / w p /$ index.php/category/environment-space/. Accessed 3 Mar 2019.

Central Bureau of Statistics. (2016b). Housing and accommodation in recent decades in Aruba. Retrieved from http://cbs.aw/wp/index.php/category/environment-space/. Accessed 3 Mar 2019.

Central Bureau of Statistics. (2016c). The suburbanization of the Aruban landscape. Retrieved from http://cbs. aw/wp/index.php/category/environment-space/. Accessed 3 Mar 2019.

Central Bureau of Statistics. (2018). Labor market statistics. Retrieved from http://cbs.aw/wp/. Accessed 22 Mar 2019.

Central Bureau of Statistics. (2019). Income and expenditure survey 2016. Retrieved from https://cbs.aw/wp/ index.php/2019/04/04/income-expenditure-survey-2016/. Accessed 2 June 2019.

Centrale Bank de Aruba. (2019). Annual statistical digest 2018. Oranjestad: CBA.

Chamon, M., Charap, J., Chen, Q., \& Leigh, D. (2017). Reinvigorating growth in the Caribbean. In T. Alleyne, I. Otker, U. Ramakrishnan, \& K. Srinivasan (Eds.), IMF (2017). Unleashing growth and strengthening resilience in the Caribbean. Washington DC: IMF Publications.

Cloutier, S., Ehlenz, M. M., \& Afinowich, R. (2019). Cultivating community wellbeing: Guiding principles for research and practice. International Journal of Community Well-Being, 2, 277-299.

Cohen, E. (1978). Impact of tourism on the physical environment. Annals of Tourism Research, 5(2), 215-237.

Cole, S. (2007). Beyond the resort life cycle: The micro-dynamics of destination tourism. Tourism and Regional Science, 37(3), 266-278.

Cole, S., \& Razak, V. (2009). How far, and how fast? Population, culture, and carrying capacity in Aruba. Futures, 41, 414-425.

Cowen, M. P., \& Shenton, R. W. (1996). Doctrines of development. New York: Routledge.

Crandall, L. (1994). The social impact of tourism on developing regions and its measurement. In J. R. B. Ritchie \& C. R. Goeldner (Eds.), Travel, Tourism and Hospitality Research. A Handbook for Managers and Researchers (2nd ed.). Toronto: John Wiley \& Sons.

Creswell, J. W., \& Creswell, J. D. (2018). Research design: Qualitative, quantitative, and mixed methods approaches (5th ed.). Los Angeles: SAGE Publishing.

Daye, M., Chambers, D., \& Roberts, S. (2008). New perspectives in Caribbean tourism. New York: Routledge.

De Vita, C., Kyaw, K.S. (2016). Tourism development and growth. Annals of Tourism Research, 60, 23-26 
Dehoorne, O., Murat, C. \& Petit-Charles, N. (2010). International tourism in the Caribbean area: Current status and future prospects, Etudes Caribeennes. Retrieved from https://journals.openedition.org/ etudescaribeennes/4713?lang=en. Accessed 8 Feb 2012.

Dobson, J. (2020). The future of Aruba: How the tiny Caribbean Island is bracing for major new hotel development, Forbes. Retrieved from https:/www.forbes.com/sites/jimdobson/2020/02/15/the-future-ofaruba-how-the-tiny-caribbean-island-is-bracing-for-major-new-hotel-development/\#260c622e285c. Accessed 17 Feb 2020.

Dodds, R., \& Butler, R. W. (2019). Over-tourism: Issues, realities and solutions. De Gruyter studies in tourism. Oldenbourg: De Gruyter.

Doxey, G. (1975). A Causation Theory of Visitor-Resident Irritants: Methodology and Research Inferences. In: The Impact of Tourism, the Sixth Annual Conference Proceedings, pp.195-198. San Diego: The Travel Research Association.

Dunkel, D. R. (1984). Tourism and the environment: A review of the literature and issues. Environmental Sociology, 37, 5-18.

Duval, D. T. (Ed.). (2004). Tourism in the Caribbean. Trends, development, prospects. Routledge: London.

Eisenhardt, K. M. (1989). Building theories from case study research. Academy of Management, 14(4), 532-550.

Farrell, B., \& Runyan, D. (1991). Ecology and tourism. Annals of Tourism Research, 18, $26-40$.

Farrell, B., \& Twinning-Ward. (2004). Reconceptualizing tourism. Annals of Tourism Research, 31(2), 274 295.

Getz, D. (1983). Capacity to absorb tourism: Concepts and implications or strategic planning. Annals of Tourism Research, 10(2), 239-263.

Giampiccoli, A., \& Saayman, M. (2018). Community-based tourism development model and community participation. African Journal of Hospitality, Tourism and Leisure, 7(4), 1-27.

Glaser, B. (1992). Basics of grounded theory analysis. Mill Valley: Sociology Press.

Gossling, S. (2002). Global environmental consequences of tourism. Global Environmental Change, 12(4), 283-302.

Government of Aruba. (2012). Two steps ahead. Tourism policy 2012. Oranjestad, Aruba, Government of Aruba.

Government of Aruba. (2019). Economic Policy: A Strong and Resilient Economy 2019-2022. Retrieved from https://www.deaci.aw/wp-content/uploads/assets/Economic-Policy-a-strong-and-resilient-economy-20192022.pdf. Accessed 19 Sept 2019.

Gretzel, U., Scarpino, J., \& M. (2018). Destination resilience and smart tourism destinations. Tourism Review International, 22(3-4), 263-267.

Gupta, J., \& Vegeling, C. (2016). Sustainable development goals and inclusive development. International Environmental Agreements, 16, 433-448.

Hall, C. M., \& Williams, A. M. (2008). Tourism and innovation. Oxon: Routledge.

Hampton, M. P., \& Jeyacheya, J. (2013). Tourism and inclusive growth in small island developing states. London: Commonwealth Secretariat.

Higgins-Desbiolles, F. (2018). Sustainable tourism: Sustaining tourism or something more? Tourism Management Perspectives, 25, 157-160.

Holder, J. (1988). Pattern and impact of tourism on the environment of the Caribbean. Tourism Management, $9(2), 119-227$.

Ianchovichina, E., \& Lundstrom, S. (2009). Inclusive Growth Analytics: Framework and Application, policy research working paper, no. 4851. Washington, DC: World Bank.

Innskeep, E. (1994). National and regional tourism planning: Methodologies and case studies. London: Routledge.

International Monetary Fund (IMF). (1997). Kingdom of the Netherlands - Aruba: 1997 Article IV Consultation Press Release. Retrieved from https://www.imf.org/en/News/Articles/2015/09/28/04/53/ pn9701. Accessed 6 June 2019.

International Monetary Fund (IMF) (2017). Building resilience in developing countries vulnerable to large natural disasters. Retrieved from https:/www.imf.org/en/Publications/Policy-Papers/Issues/2019/06/24/BuildingResilience-in-Developing-Countries-Vulnerable-to-Large-Natural-Disasters-47020. Accessed 25 Aug 2015.

International Monetary Fund (IMF). (2019). Kingdom of the Netherlands - Aruba: 2019 Article IV Consultation Discussions-Press Release and Staff Report. Retrieved from https://www.imf.org/en/ Publications/CR/Issues/2019/06/03/Kingdom-of-the-Netherlands-Aruba-2019-Article-IV-ConsultationDiscussions-Press-Release-and-46958. Accessed 6 June 2019.

Island Resource Foundation. (1996). Tourism and coastal resources degradation in the wider Caribbean. A Study for the United Nations Environment Programme, Caribbean Environment Programme, Regional 
Coordinating Unit, Kingston, Jamaica. St. Thomas, Virgin Islands, December, 1996, Island Resources Foundation.

Joppe, M. (2019). The roles of policy, planning, and governance in preventing and managing over-tourism. In R. Dodds \& R. W. Butler (Eds.), Over-tourism: Issues, realities and solutions, De Gruyter studies in tourism. Oldenbourg: De Gruyter.

Koens, K., Postma, A., \& Papp, B. (2018). Is over-tourism overused? Understanding the impact of tourism in a city context. Sustainability, 10, 4384.

Kohr, L. (1977). The overdeveloped nations: The diseconomies of scale. Swansea: Christopher Davies Publishers.

Leigh, D., Srinivasan, K., \& Werner, A. (2017). Unleashing strong, sustainable, and inclusive growth in the Caribbean. In T. Alleyne, I. Otker, U. Ramakrishnan, \& K. Srinivasan (Eds.), IMF (2017). Unleashing growth and strengthening resilience in the Caribbean. Washington DC: IMF Publications.

Lenzen, M., Sun, Y., Faturay, F., Ting, Y., Geschke, A., \& Malik, A. (2018). The carbon footprint of global tourism. Nature Climate Change, 8, 522-528.

Marsiglio, S. (2017). On the carrying capacity and the optimal number of visitors in tourism destinations. Tourism Economics, 23(3), 632-646.

Marsiglio, S. (2018). On the implications of tourism specialization and structural change in tourism destinations. Tourism Economics: the Business and Finance of Tourism and Recreation, 24(8), 945-962.

Mathieson, A., \& Wall, G. (1982). Tourism; economic, physical and social impacts. Harlow: Longman.

McCool, S., \& Lime, D. (2001). Tourism carrying capacity: Tempting fantasy or useful reality? Journal of Sustainable Tourism, 9(5), 372-387.

McElroy, J. L. (2003). Tourism development in Small Islands across the world. Geografiska Annaler Human Geography, 85(4), 231-242.

McElroy, J. L., \& De Albuquerque. (2002). Problems for managing sustainable tourism in small islands. In Y. Apostolopoulos \& D. J. Gayle (Eds.), Island tourism and sustainable development: Caribbean, Pacific, and Mediterranean experiences. Praeger: Wesport.

McElroy, J. L., \& Pearce, K. B. (2006). The advantages of political affiliation: Dependent and independent small-island profiles. The Round Table, 95(386), 529-539.

Meier, G. M. (2001). The Old Generation of Development Economics and the New. In G. M. Meier \& J. E. Stiglitz (Eds.), Frontiers of development economics. The Future in Perspective. Oxford: Oxford University Press.

Meier, G. M., \& Stiglitz, J. E. (2001). Frontiers of development economics. The Future in Perspective. Oxford: Oxford University Press.

Milano, C., Novelli, M., \& Cheer, J. M. (2019). Over-tourism and tourismphobia: A journey through four decades of tourism development, planning and local concerns. Tourism Planning and Development, 16(4), 353-357.

Moscardo, G. (2008). Building community capacity for tourism development. Wallingford: CAB International.

Moscardo, G. (2015). Social capital, trust and tourism development. In R. Nunkoo \& S. L. J. Smith (Eds.), Trust, tourism development and planning, Contemporary geographies of leisure, tourism and mobility (Vol. 47, pp. 64-85). Abingdon: Routledge.

Moscardo, G. (2019). Rethinking the role and practice of destination community involvement in tourism planning. In K. Andriotis, D. Stylidis, \& A. Weidenfeld (Eds.), Tourism policy and planning implementation, Contemporary geographies of leisure, tourism and mobility (pp. 36-52). London: Routledge.

Musikanski, L., Rogers, R., Smith, S., \& Koldowski, J. (2019). Planet happiness: A proposition to address Overtourism and guide responsible tourism, Happiness, Well-being and Sustainability in World Heritage Sites and Beyond. International Journal of Community Well-Being, 2, 359-371.

National Tourism Council (NTC). (2003). Aruban sustainable tourism framework. Kingston: Government of Aruba.

Pattulo, P. (1996). Last resorts: The cost of tourism in the Caribbean. 2nd ed, 2005. New York: Monthly Review Press.

Pearce, D. G. (1985). Tourism and environmental research: A review. International Journal of Environmental Studies, 25, 247-255.

Pearce, D. G., \& Butler, R. W. (1999). Contemporary issues in tourism development. London: Routledge.

Peterson, R. R. (2006). The quest for sustainable tourism. Kingston: Central Bank of Aruba.

Peterson, R. R. (2009). Seeking sustainability of tourism specialization in Small Island states. International tourism conference, University of the West Indies, Barbados.

Peterson, R. R. (2016). Institutional capabilities for Island Innovation. In: The Caribbean in a changing world: Surveying the past, Mapping the future (Vol. 1). Cambridge Scholars Publishing.

Peterson, R. R. (Editor, 2019). Fostering economic resilience: From roots to routs. Central Bank of Aruba. Retrieved from https://www.cbaruba.org/cba/readBlob.do?id=5788. Accessed 10 Sept 2019. 
Peterson, R. R., Harrill, R., \& DiPietro, R. (2017). Sustainability and Resilience in Caribbean Tourism Economies: A Critical Inquiry. Tourism Analysis, 22(3), 407-419 (13).

Peterson, R. R., DiPietro, R. \& and Harrill, R. (2020). In search of inclusive tourism in the Caribbean: Insights from Aruba, Worldwide Hospitality and Tourism Themes, 12 (3), 225-243.

Polanyi, K. (1944). The great transformation. The political and economic origin of our time. Boston: Beacon Press.

Ranieri, R. \& Ramos, R. (2013). Inclusive growth: Building up a concept. Working paper, no. 104, International policy Centre for Inclusive Growth. Brasilia: UNDP.

Rauniyar, G., \& Kanbur, R. (2010). Inclusive development: Two papers on conceptualization, application, and the $A D B$ perspective. Asian Development Bank: Mandaluyong City.

Raworth, K. (2017). Doughnut economics. Seven ways to think like a 21st century economist. Vermont: Chelsea Green Publishing.

Richter, L. K. (1994). The political dimensions tourism. In J. R. B. Ritchie \& C. R. Goeldner (Eds.), Travel, Tourism and Hospitality Research. A Handbook for Managers and Researchers (2nd ed.). Toronto: John Wiley \& Sons.

Ruprah, I., Melgarejo, K. A. \& Sierra, R. (2014). Is there a caribbean sclerosis? Stagnating economic growth in the Caribbean. Washington: Inter-American Development Bank, Country Department Caribbean.

Scheyvens, R. \& Biddulph, R. (2017). Inclusive Tourism Development, Journal of Tourism Geographies: An International Journal of Tourism Space, Place and Environment, 20 (4), 589-609.

Shani, A., Uriely, N., Reichel, A., \& Ginsburg, L. (2014). Emotional labor in the hospitality industry: The influence of contextual factors. International Journal of Hospitality Management, 37, 150-158.

Sheller, M. (2003). Consuming the Caribbean: From Arawaks to zombies. New York: Routledge.

Sönmeza, S., Apostolopoulos, Y., Lemke, M. K., Hsiehd, Y., \& Karwowskie, W. (2017). Complexity of occupational health in the hospitality industry: Dynamic simulation modeling to advance immigrant worker health. International Journal of Hospitality Management, 67(October), 95-105.

Stiglitz, J. (2013). The Price of inequality. New York: Penguin Group.

United Nations Development Program (UNDP). (1996). Executive Board of the United Nations Development Programme and of the United Nations Population Fund. Retrieved from http://web.undp.org/execbrd/ archives/sessions/eb/1st-2nd-1996/DP-1996-5.pdf. Accessed 6 June 2019.

United Nations Sustainable Development Goals (UNSDG). 2018). The Sustainable Development Goals report 2018. Retrieved from https://www.un.org/development/desa/publications/the-sustainable-developmentgoals-report-2018.html. Accessed 10 June 2019.

United Nations World Tourism Organization (UNWTO) (2018). Overtourism? - understanding and managing urban tourism growth beyond perceptions, executive summary. Retrieved on 29 April from https://doi. org/10.18111/9789284420070.

VanderWeele, T. J. (2019). Measures of community well-being: A template. International Journal of Community Well-Being, 2, 253-275.

Wilkinson, P. F. (1989). Strategies for tourism in island microstates. Annals of Tourism Research, 16, 153177.

Williams, P. W., \& Ponsford, I. F. (2008). Confronting tourism's environmental paradox: Transitioning for sustainable tourism. Futures, 41, 396-404.

World Bank. (2018). Inclusive growth: A synthesis of findings from recent IEG evaluations. Washington, D.C: World Bank Group.

World Travel and Tourism Council (WTTC). (2019). Economic impact research report 2019. Retrieved from https:/www.wttc.org/economic-impact/country-analysis/. Accessed 29 Apr 2019.

Yin, R. K. (2009). Case study research. Design and Methods. Thousand Oaks: Sage Publications.

Publisher's Note Springer Nature remains neutral with regard to jurisdictional claims in published maps and institutional affiliations. 